\title{
Influence of Selenium on Growth, Antioxidants Production and Physiological Parameters of Rice (Oryza sativa L.) Seedlings and Its Possible Reversal by Coapplication of Sulphate
}

\author{
Debarati Das, Paulin Seal, Asok K. Biswas* \\ Plant Physiology and Biochemistry Laboratory, Centre of Advanced Study, Department of Botany, University of Calcutta, Kolkata, \\ India \\ Email: *asokbiswas2016@yahoo.com
}

How to cite this paper: Das, D., Seal, P. and Biswas, A.K. (2019) Influence of Selenium on Growth, Antioxidants Production and Physiological Parameters of Rice (Oryza sativa L.) Seedlings and Its Possible Reversal by Coapplication of Sulphate. American Journal of Plant Sciences, 10, 2236-2278.

https://doi.org/10.4236/ajps.2019.1012158

Received: October 22, 2019

Accepted: December 22, 2019

Published: December 25, 2019

Copyright $\odot 2019$ by author(s) and Scientific Research Publishing Inc. This work is licensed under the Creative Commons Attribution International License (CC BY 4.0).

http://creativecommons.org/licenses/by/4.0/

\begin{abstract}
The effect of selenate $\left(\mathrm{Na}_{2} \mathrm{SeO}_{4}\right)$ and sulphate $\left(\mathrm{Na}_{2} \mathrm{SO}_{4}\right)$ was studied on growth and metabolism in two rice cultivars cv. satabdi and cv. khitish. Selenate at low concentration $(2 \mu \mathrm{M})$ expressed growth promoting effect on rice seedlings as opposed to its high concentration $(\geq 20 \mu \mathrm{M})$ where the test seedlings showed stunted growth with browning at the apices of both roots and shoots. The chlorophyll contents showed a dose dependent effect. Both chlorophyll a and chlorophyll b contents were inhibited with increase in selenate concentrations. The effect was more pronounced in cv. satabdi compared to $\mathrm{cv}$. khitish.The level of accessory pigments was deferentially affected by selenium treatment. Simultaneously, the fluorescence intensity and Hill activity decreased with increase in selenate concentrations in the test seedlings. It is assumed that selenium plays a protective role in plants subjected to stress and prevents the formation of reactive oxygen species (ROS) in the cells. Higher selenate concentrations $(\geq 20 \mu \mathrm{M})$ exerted variable effect on the activities of enzymatic antioxidants viz.; superoxide dismutase (SOD), catechol peroxidase (CPX) and catalase (CAT) in the test seedlings. The activity of SOD increased with increase in selenate concentrations, whereas activities of CAT and CPX decreased. Under high selenate concentrations, the levels of oxidative stress markers, viz.; proline, $\mathrm{H}_{2} \mathrm{O}_{2}$ and MDA were also enhanced. Selenium induced accumulation of total soluble sugar and increased the level of both reducing and non reducing sugars in both the test cultivars. The starch contents concomitantly decreased with rise in selenate concentrations. Moreover, the nutrient contents of test seedlings were significantly influenced by selenium. The $\mathrm{Na}$ and $\mathrm{K}$ levels gradually increased whereas $\mathrm{Ca}, \mathrm{Mg}$ and $\mathrm{Fe}$
\end{abstract}


levels decreased on application of selenate. Joint application of $10 \mathrm{mM}$ sulphate and selenate showed significant alterations on all parameters tested with respect to selenate treatment alone. Partial to complete amelioration occurred in the test seedlings treated with high concentrations of selenate and sulphate. Our study shows that selenium at low concentration had a stimulatory effect on growth and metabolism as against high concentrations which proved to be toxic to the rice seedlings obtained from both the cultivars. Effects were more pronounced in cv. satabdi than in cv. khitish which is considered to be comparatively tolerant to selenium. The dose dependent influence of selenium on the physiological and biochemical responses of test seedlings may be reversed by co-application with sulphate.

\section{Keywords}

Rice, Selenate, Sulphate, Growth, Biochemical Changes

\section{Introduction}

Selenium (Se), belonging to oxygen sulphur family, acts as an essential micronutrient as well as an antioxidant in microbes and animals but its role in plants is debatable. The narrow margin between the beneficial and harmful levels of Se has important implications for human health. Selenium evidently possesses antidiabetic, immunostimulating, cardio-protective, antiviral, anti-carcinogenic and detoxification properties [1]. Plant sources of selenium are more bioavailable than animal sources but the translocation of selenium from root to shoot is dependent on the form of selenium supplied [2]. In plants, Se is primarily absorbed as selenite or selenate from soil. It is then translocated to the chloroplast, where it follows the sulfur assimilation pathway [3]. Selenium and sulphur being chalcogens compete readily for their uptake in plants as both anions are taken up via sulphate transporter(s) in the root plasma membrane [4] [5].

Although Se is not regarded as a micronutrient for higher plants [6], studies in different plant species have shown that at low concentration selenium exerts beneficial effect on growth and stress tolerance [7] [8] [9]. Selenium at low concentration stimulates the growth of Astragalus, Arabidopsis, Brassica and Stanleya but the presence of sulphate ions influences the uptake of Se in these species [10] [11] [12] [13]. Selenium not only regulates water status of plants under drought conditions [14], it also confers resistance against oxidative stress in them [15] by enhancing the activities of both enzymatic antioxidants like superoxide dismutase (SOD), catalase (CAT), catechol peroxidase (CPX) and non enzymatic antioxidants like GSH, ascorbate and carotenoids [16]. However, at high concentrations, Se is phytotoxic and accelerates accumulation of reactive oxygen species (ROS) [17]. Uptake of high concentration of Se by plant roots may lead to symptoms of injury including stunted growth, chlorosis, withering and drying of leaves, decreased protein synthesis and also premature death [18]. 
Selenosis due to high Se accumulation leads to malformed selenoproteins that alter redox potential, induce oxidative stress and affect enzyme kinetics [19]. Selenate also compromises membrane integrity accompanied by increased activity of ROS-scavenging enzymes, including superoxide dismutase, catalase and peroxidase [20] [21].

Fe-S cluster proteins of chloroplast and mitochondria are susceptible to Se-induced damages and interfere with chlorophyll synthesis as well as respiratory processes [22]. Se induced interference in pigment synthesis possibly affects the photosynthetic machinery which reduces synthesis of starch and alters carbohydrate metabolism. Detoxification of ROS is however accomplished by an up regulation in enzymatic and non-enzymatic scavenging systems inside the plant [23].

Malnutrition is predominant in developing countries where almost half the population suffers from diseases caused by deficiency in essential mineral uptake. Nutritional disorders due to the mineral elements may manifest as deficiency or excesses of particular elements. Minerals are important chemical elements which act as essential nutrients for plants and aid in various metabolic activities. They are absorbed from the soil by plants in the form of organic and inorganic ions. Plant tissues are able to bind metals as the various functional groups present in them can attract and sequester the metallic ions [24]. In plants the sequestered ions act as structural components in carbohydrates and proteins; organic molecules in metabolism (viz., magnesium in chlorophyll and phosphorus in ATP), enzyme activators and channel facilitators like potassium and sodium, and also as osmoticum for maintaining osmotic balance. Ions like $\mathrm{Cu}, \mathrm{Fe}$, $\mathrm{Se}, \mathrm{Mn}$ and $\mathrm{Zn}$ form an integral part of enzymatic antioxidants and sufficient amount of trace elements like $\mathrm{Fe}, \mathrm{Cu}$ and $\mathrm{Zn}$ are required for energy production as well as to provide protection from the highly toxic reactive oxygen species. Trace metals or minerals have significant roles to play in the catalytic activities of major antioxidant enzymes during maturation, activation and defence mechanisms of the cell [25].

Surplus of Se inhibits the absorption of metals, mainly $\mathrm{Mn}, \mathrm{Zn}, \mathrm{Cu}$, and $\mathrm{Cd}$ and causes deficiency of nutrients in plants [26]. Deficiency in essential mineral uptake not only affects physiological processes but also generates nutritional disorders in plants and subsequently in humans. The mineral constituents are either directly or indirectly influenced by various factors which affect their availability to humans and animals from different dietary sources. Knowledge of the importance of the mineral elements in plants is essential as the global trend in nutrition and medicine is shifting towards the use of plant as fruits and vegetables and phyto-medicines [27]. Part of our work was to evaluate the mineral composition of test seedlings under the influence of Se salt on nutrients accumulation in the two rice cultivars cv. khitish and cv. satabdi. The potentially deleterious effects of Se contamination in agricultural areas with large selenate content in the soil may be controlled by $\mathrm{S}$ application as a close relationship exist 
between Se and S metabolism in plants due to their physical and chemical similarities. Selenate competes with the high-affinity sulfate transporter sultr1; 1 for influx in the roots and its toxicity is progressively reduced in presence of increasing levels of sulphate in the rhizosphere because high sulphate concentrations in the rhizosphere reduce selenate uptake [28] [29].

Biofortification or enriching crop tissues which act as potential dietary source by exogenous supplementation of bioavailable elements is a promising way to counteract the menace posed by nutrient deficiencies [30]. With this point in view the importance of obtaining an adequate crop yield with suitable nutrient concentration of macronutrients especially $\mathrm{Na}, \mathrm{K}, \mathrm{Ca}$ and micronutrient such as Fe have been studied. The knowledge obtained on the nutritional status of a plant in presence of Se and under the influence of co-application of Se and S will subsequently shed light on the functional state of the test cultivars cv. satabdi and cv. khitish.

Rice is an important crop plant which forms the staple food for about half of the world population. Rice (Oryza sativa L.) also forms one of the most predominant cereal crops in Eastern India including West Bengal. Presently farmers prefer to cultivate hybrid rice varieties as they are cost productive and can withstand or counteract stresses induced by various biotic and abiotic factors. Hybrid rice varieties such as cv. Satabdi (drought sensitive) and cv. Khitish (drought resistant) are much in demand in West Bengal due to the finer quality of the grains as well as higher market value. So, we based our study on these two cultivars of rice. Se biofortified rice may act as important dietary source to human and provide the necessary nutrients required to alleviate health issues related to its deficiency. Standardization of ideal strategy to increase Se level in rice plants has to be developed which is both economically and agronomically suitable for human consumption [1]. With this perspective, our study was focused on the influence of selenate, the readily bioavailable form of inorganic Se in the environment on the above mentioned cultivars of rice.

\section{Plant Material and Selenium Treatment}

Rice (Oryza sativa L.) seeds cv. Satabdi (IET 4786) and cv. khitish (IET 4094) were obtained from the State Rice Research Station, Chinsurah, Hoogly, West Bengal. The seeds were surface sterilized with sodium hypochlorite $(5 \% \mathrm{w} / \mathrm{v})$ and thoroughly washed with distilled water. The petridishes of diameter- $10 \mathrm{~cm}$ lined with filter papers contained about 100 seeds for each treatment. The petridishes were kept in dark and humid condition for 72 hours at $30^{\circ} \mathrm{C} \pm 2{ }^{\circ} \mathrm{C}$ in a germinator. After germination, the seedlings were grown hydroponically in modified Hoagland solution with various concentrations $(2 \mu \mathrm{M}, 10 \mu \mathrm{M}, 20 \mu \mathrm{M}$, $50 \mu \mathrm{M})$ of sodium selenate $\left(\mathrm{Na}_{2} \mathrm{SeO}_{4} \cdot 7 \mathrm{H}_{2} \mathrm{O}\right.$; Loba-Chemie, India)with or without $10 \mathrm{mM}$ sodium sulphate $\left(\mathrm{Na}_{2} \mathrm{SO}_{4}\right.$; Merck, India). The test seedlings were then exposed to $16 \mathrm{~h}$ photoperiod $\left(260 \mu \mathrm{mol} \cdot \mathrm{m}^{-2} \cdot \mathrm{s}^{-1} \mathrm{PFD}\right)$ and harvested after a total of 21 days for the following studies. 


\subsection{Growth and Water Content Measurements}

From 21 days rice seedlings the root and shoot lengths of selenate treated and untreated seedlings were measured. Then, 10 seedlings from each set were harvested and weighed. The selected seedlings were allowed to dry at $70^{\circ} \mathrm{C}$ for 4 days and then at $100^{\circ} \mathrm{C}$ for 3 days after which the dry weights of the samples were taken. To determine water contents, the differences between fresh weight and dry weight of the seedlings were recorded [31].

\subsection{Extraction and Estimation of Selenium and Mineral Content}

Total selenium contents were measured from 21 days old test seedlings treated with selenate with or without sulphate by acid digestion of oven dried samples. Dried samples ( $2 \mathrm{~g}$ each) of test seedlings were digested in a microwave digestor using $7 \mathrm{ml} \mathrm{HNO}_{3}$ (65\%), $5 \mathrm{ml} \mathrm{HCl}$ and $2 \mathrm{ml} \mathrm{H}_{2} \mathrm{O}_{2}$ for 60 minutes [32]. Selenium contents of the rice samples were determined by Inductively Coupled Plasma Optical Emission Spectrophotometer (ICP-OES) Model No 6300 DUO (Thermofischer) with flow injection hydride generation system, using a standard curve prepared from known concentrations of selenium respectively. The selenium contents were expressed in terms of $\mathrm{mg} \cdot \mathrm{kg}^{-1} \mathrm{DW}$. Element concentrations of $\mathrm{K}, \mathrm{Ca}, \mathrm{Na}$, $\mathrm{Mg}$ and Fe were analyzed with a Perkin-Elmer 2001 Model Inductively Coupled Plasma-Mass Emission Spectrometry (ICP-MS) and Atomic absorption Spectrometry (AAS).The ion contents were also expressed in terms of $\mathrm{mg} \cdot \mathrm{kg}^{-1} \mathrm{DW}$.

\subsection{Chlorophyll Contents and Fluorescence Activity}

Total chlorophyll, chlorophyll-a and chlorophyll-b contents were measured from the rice leaves according to Arnon [33]. $1 \mathrm{~g}$ of fresh leaves was extracted with $25 \mathrm{ml}$ of $80 \%$ alkaline acetone $\left(0.1 \mathrm{M} \mathrm{Na}_{2} \mathrm{CO}_{3}\right)(\mathrm{v} / \mathrm{v})$. Chlorophyll contents were estimated spectrophotometrically by recording the OD at $645 \mathrm{~nm}$ and 663 nm using a Hitachi U-2000 spectrophotometer and calculations were done according to Arnon's (1949) formula as follows:

$$
\begin{gathered}
\text { Total chlorophyll }=\left[20.2\left(A_{645}\right)+8.02\left(A_{663}\right)\right] \times V / 1000 \times 1 / \mathrm{W} \\
\text { Chlorophyll-a }=\left[12.7\left(A_{663}\right)-2.69\left(A_{645}\right)\right] \times V / 1000 \times 1 / W \\
\text { Chlorophyll-b }=\left[22.9\left(A_{645}\right)-4.68\left(A_{663}\right)\right] \times V / 1000 \times 1 / W
\end{gathered}
$$

( $V=$ Final volume of chlorophyll extract in $80 \%$ acetone, $W=$ fresh weight of leaf in grams, $A=\mathrm{OD}$ value).

The chlorophyll contents were expressed in terms of mg chlorophyll present $\mathrm{g}^{-1}$. FW. The fluorescence of the chlorophyll was monitored at an excitation wavelength $640 \mathrm{~nm}$ and emission wavelength $680 \mathrm{~nm}$ with the help of a Hitachi650-40 spectro fluorometer and results were expressed as fluorescence intensity of the chlorophyll obtained from $\mathrm{g}^{-1} \mathrm{FW}$.

\subsection{Carotenoid Contents}

Carotene and xanthophyll contents were estimated according to the protocol 
described by Mukherji and Biswas [34]. $20 \mathrm{ml}$ of cyclohexane was mixed with the pigmented alkaline acetone solution in a separating funnel. The hexane layer was washed with $20 \mathrm{ml}$ of water. Xanthophylls were removed from the upper hexane layer containing carotene by repeated extraction with $20 \mathrm{ml}$ of $90 \%$ methanol (v/v). Carotene and xanthophyll contents were measured by utilizing the values of absorbance at $425 \mathrm{~nm}$ and $450 \mathrm{~nm}$ respectively using a Hitachi $\mathrm{U}-2000$ spectrophotometer and data were expressed in terms of $\mathrm{OD} \mathrm{g}^{-1} \mathrm{FW}$.

\subsection{Hill Activity}

Hill activity was assayed according to Vishniac [35]. $1 \mathrm{~g}$ fresh green leaves were extracted in $5 \mathrm{ml}$ sucrose-phosphate buffer $(0.4 \mathrm{M}$ sucrose in $0.05 \mathrm{M}$ sodium phosphate buffer) at $\mathrm{pH} 6.2$ and centrifuged at $2000 \mathrm{~g}$ for 10 minutes. The pellet was discarded and the supernatant was recentrifuged at $8000 \mathrm{~g}$ for 20 minutes. Now the pellet containing chloroplasts were resuspended in $5 \mathrm{ml}$ sucrose-phosphate buffer. The reaction mixture consisted of $1 \mathrm{ml}$ chloroplast

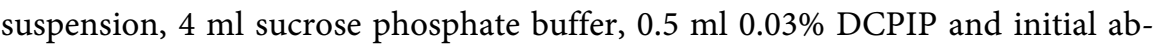
sorbance was recorded at $610 \mathrm{~nm}$ using Hitachi U-2000 spectrophotometer. The reaction mixtures were kept in bright sunlight for 5 minutes and discolouration of DCPIP was recorded at $610 \mathrm{~nm}$. The difference in OD was converted in terms of $\mu$ mole DCPIP photoreduced from a standard curve using known concentrations of DCPIP. Also the chlorophyll contents of the isolated chloroplast were measured according to the method of Arnon [33]. Hill activity was expressed as $\mu$ mole DCPIP photoreduced $\mathrm{mg}^{-1}$ chlorophyll $\mathrm{min}^{-1}$.

\subsection{Extraction and Assays of Antioxidant Enzymes}

Enzyme extraction procedures were carried out at $4^{\circ} \mathrm{C} .1 \mathrm{~g}$ of plant sample from each treatment was homogenized in $5 \mathrm{ml}$ of pre-chilled $0.1 \mathrm{M}$ sodium phosphate buffer ( $\mathrm{pH}$ 7.0). The homogenate was centrifuged at $12,000 \mathrm{~g}$ for 20 minutes and supernatant was used to assay the enzymes activities.

\subsubsection{Assay of Superoxide Dismutase (SOD) Activity}

Superoxide dismutase (EC 1.15.1.1) activity was assayed by using the nitroblue tetrazolium method [36]. The reaction mixture contained $2.5 \mathrm{ml}$ of $80 \mathrm{mM}$ Tris-HCl buffer ( $\mathrm{pH}$ 7.5) containing $0.12 \mathrm{mM}$ EDTA and 10.8 mM TEMED, 0.1 $\mathrm{ml} 0.0033 \% \mathrm{BSA}, 0.1 \mathrm{ml} 6 \mathrm{mM} \mathrm{NBT}, 0.1 \mathrm{ml}$ of $0.6 \mathrm{mM}$ riboflavin and $0.1 \mathrm{ml} \mathrm{en-}$ zyme extract. The reaction was started by the addition of riboflavin, and the glass tube was shaken and placed under a fluorescent lamp $\left(60 \mu \mathrm{mol} \cdot \mathrm{m}^{-2} \cdot \mathrm{s}^{-1}\right)$. The reaction was allowed to proceed for 10 minutes and was stopped by switching off the light. The absorbance was measured at $560 \mathrm{~nm}$. Blank and control were run in the same manner but without illumination and enzyme respectively. One unit of SOD was defined as the amount of enzyme that produced $50 \%$ inhibition of NBT reduction under assay condition. Enzyme activity was expressed as EU SOD $\mathrm{mg}^{-1}$ protein $\mathrm{min}^{-1}$. 


\subsubsection{Assay of Catalase (CAT) Activity}

Catalase (EC 1.11.1.6) activity was determined as the amount of $\mathrm{KMnO}_{4}$ consumed in terms of $\mathrm{H}_{2} \mathrm{O}_{2}$ [37]. The reaction mixture contained $0.5 \mathrm{ml}$ of $0.1 \mathrm{M}$ sodium phosphate buffer ( $\mathrm{pH} 7.0), 1 \mathrm{ml}$ of $3 \% \mathrm{H}_{2} \mathrm{O}_{2}(\mathrm{v} / \mathrm{v})$ and $1 \mathrm{ml}$ of enzyme extract. After incubation, the reaction was stopped by adding $3 \mathrm{ml}$ of $10 \% \mathrm{H}_{2} \mathrm{SO}_{4}$ $(\mathrm{v} / \mathrm{v})$. The residual $\mathrm{H}_{2} \mathrm{O}_{2}$ was titrated against $0.02 \mathrm{~N} \mathrm{KMnO}_{4}$. The enzyme activity was expressed in terms of $\mathrm{mg} \mathrm{H}_{2} \mathrm{O}_{2}$ decomposed $\mathrm{mg}^{-1}$ protein $\mathrm{min}^{-1}$.

\subsubsection{Assay of Catechol Peroxidase (CPX) Activity}

Catechol peroxidase (EC 1.11.1.7) activity was assayed spectrophotometrically [38] using a Hitachi U-2000 spectrophotometer. The reaction mixtures contained $5 \mathrm{ml}$ of $0.1 \mathrm{M}$ sodium phosphate buffer ( $\mathrm{pH} 7.0), 1 \mathrm{ml}$ of $10 \% \mathrm{H}_{2} \mathrm{O}_{2}(\mathrm{v} / \mathrm{v}$ ), $1 \mathrm{ml}$ of $0.5 \%$ catechol (w/v) and $1 \mathrm{ml}$ enzyme extract. The absorbance values of reaction mixtures were recorded at $480 \mathrm{~nm}$ at 0 time and after incubation for 1 minute. The enzymatic activity was expressed in terms of change in absorbance, $\mathrm{A}_{480} \mathrm{mg}^{-1}$ protein $\mathrm{min}^{-1}$.

\subsection{Proline Content}

$1 \mathrm{~g}$ of sample from 21 days old rice seedlings was extracted with $5 \mathrm{ml}$ of $0.1 \mathrm{M}$ sulpho salicylic acid and centrifuged at $5000 \mathrm{~g}$ for 30 minutes [39]. To $2 \mathrm{ml}$ of supernatant, $5 \mathrm{ml}$ GAA and $5 \mathrm{ml}$ of $140 \mathrm{mM}$ acid ninhydrin were added and shaken vigorously. The mixture was heated in a boiling water bath and after cooling, the mixture was extracted in $10 \mathrm{ml}$ of toluene in a separating funnel and aqueous layer was discarded. The absorbance of the mixture was measured at $520 \mathrm{~nm}$. The proline content was calculated from standard curve and expressed as $\mu \mathrm{g} \cdot \mathrm{g}^{-1} \mathrm{FW}$.

\subsection{Hydrogen Peroxide $\left(\mathrm{H}_{2} \mathrm{O}_{2}\right)$ Content}

The $\mathrm{H}_{2} \mathrm{O}_{2}$ content from root and shoot samples from 21 days old rice seedlings were measured as described by Velikova et al. [40]. $1 \mathrm{~g}$ tissue was extracted with $5 \mathrm{ml}$ of trichloro acetic acid $(0.1 \%, \mathrm{w} / \mathrm{v})$ at $4^{\circ} \mathrm{C}$ and homogenate was centrifuged at $12,000 \mathrm{~g}$ for 15 minutes. To $0.5 \mathrm{ml}$ of supernatant, $0.5 \mathrm{ml}$ of $0.05 \mathrm{M}$ sodium phosphate buffer ( $\mathrm{pH}$ 7.0) and $1 \mathrm{ml}$ of $1 \mathrm{M}$ potassium iodide (KI) solution were added. The absorption of the mixture was measured at $390 \mathrm{~nm}$. The $\mathrm{H}_{2} \mathrm{O}_{2}$ content was determined using an extinction coefficient $(\varepsilon)$ of $0.28 \mu \mathrm{M}^{-1} \cdot \mathrm{cm}^{-1}$ and expressed as $\mu \mathrm{mol} \cdot \mathrm{g}^{-1} \mathrm{FW}$.

\subsection{Malondialdehyde Content (Lipid Peroxidation)}

Lipid peroxidation in terms of malondialdehyde (MDA) contents was determined to assess the membrane damage in rice seedlings. For the measurement of lipid peroxidation, the thiobarbituric acid (TBA) test was used to measure MDA level as an end product of lipid peroxidation [41]. $1 \mathrm{~g}$ tissue was homogenized in $4 \mathrm{ml}$ of $1 \%$ trichloroacetic acid (TCA) solution (w/v) and centrifuged at 10,000 g for 10 minutes. The supernatant was mixed with $1 \mathrm{ml}$ of $0.5 \%$ TBA in $20 \%$ TCA 
$(w / v)$. The mixture was incubated in boiling water for 30 minutes and the reaction was stopped by placing the tubes in an ice bath. The samples were re-centrifuged at 10,000 $\mathrm{g}$ for 5 minutes and the absorbance values of the supernatants were measured at $532 \mathrm{~nm}$. The values for nonspecific absorption at 600 $\mathrm{nm}$ were subtracted. The amount of MDA-TBA complex present was calculated using an extinction coefficient $(\varepsilon)$ of $155 \mathrm{mM}^{-1} \cdot \mathrm{cm}^{-1}$ and expressed as $\mu \mathrm{mol} \cdot \mathrm{g}^{-1}$ FW.

\subsection{Total Soluble Sugar Content}

The amount of total soluble sugar was estimated by phenol sulphuric acid reagent method [42]. $1 \mathrm{~g}$ of fresh shoot and root samples from each treatment set were homogenized with $5 \mathrm{ml} \mathrm{80 \%} \mathrm{ethanol} \mathrm{(v/v).} \mathrm{The} \mathrm{alcoholic} \mathrm{extracts} \mathrm{were}$ centrifuged at $2000 \mathrm{~g}$ for 20 minutes. To $1 \mathrm{ml}$ of supernatant, $0.05 \mathrm{ml}$ of $5 \%$ phenol solution (v/v) and $5 \mathrm{ml} 98 \% \mathrm{H}_{2} \mathrm{SO}_{4}$ were added. The mixtures were incubated in water bath at $30^{\circ} \mathrm{C}$ for 20 minutes. The OD values of the characteristic yellow orange colour were measured at $490 \mathrm{~nm}$ in a Hitachi-2000 spectrophotometer. By using standard curve of glucose, the quantity of the total soluble sugar was calculated and expressed as $\mathrm{mg} \cdot \mathrm{g}^{-1} \mathrm{FW}$.

\subsubsection{Reducing and Non-Reducing Sugar Contents}

Estimation of reducing sugar contents was done by the method of Miller [43]. 1 $\mathrm{g}$ of plant material was crushed with $5 \mathrm{ml}$ of $80 \%$ ethanol $(\mathrm{v} / \mathrm{v})$ and centrifuged at $2000 \mathrm{~g}$ for 20 minutes. To $1 \mathrm{ml}$ of alcoholic extract, $0.5 \mathrm{ml}$ of $1 \%$ (w/v) DNSA reagent was added and boiled in water bath for 5 minutes. After cooling, the absorbance was measured at $515 \mathrm{~nm}$ using a Hitachi-2000 spectrophotometer. From a standard curve of glucose, the quantity of reducing sugar was calculated and expressed as $\mathrm{mg} \cdot \mathrm{g}^{-1} \mathrm{FW}$. The amount of non-reducing sugar was measured by subtracting the value of reducing sugar from the value of total soluble sugar.

\subsubsection{Starch Content}

Estimation of starch was done by the method of Mc Cready et al. [44]. The residual mass, obtained after centrifugation for the extraction of total soluble sugar was suspended in $2.5 \mathrm{ml}$ of distilled water followed by the addition of $3.25 \mathrm{ml}$ of $52 \%(\mathrm{v} / \mathrm{v}) \mathrm{HClO}_{4}$. After stirring, the mixture was centrifuged at $2000 \mathrm{~g}$ for 20 minutes. The supernatant was collected and poured in conical flasks and the total volume was made up to $50 \mathrm{ml}$ by adding distilled water for each set. After filtration through Whatman (No. 42) filter paper, $1 \mathrm{ml}$ of filtrate from each set was taken and starch contents were measured following the same procedure as the total soluble sugar. Quantity of starch was calculated in terms of glucose and factor 0.9 was used to convert the values of glucose to starch. The quantity of starch was expressed as $\mathrm{mg} \cdot \mathrm{g}^{-1} \mathrm{FW}$.

\subsection{Estimation of Protein Content}

In all the enzyme preparations, protein contents were estimated by the method 
of Lowry et al. [45] using bovine serum albumin (BSA, Sigma) as standard.

\subsection{Statistical Analysis}

The experiments were carried out in a completely randomized design (CRD) with means of three repeats with two replicates in each time; each replication comprised a single petridish containing 100 seeds. The data and significant differences among mean values were compared by descriptive statistics $( \pm \mathrm{SE})$.

\section{Results}

\subsection{Effect on Growth}

A marked inhibition in growth of rice seedlings with increase in concentrations of selenium were observed in both roots and shoots of cv. satabdi and cv. khitish (Figure 1(a) and Figure 1(b)). The growths of roots were more affected than shoots along with browning of the apices. At $2 \mu \mathrm{M}$ selenate, the root length increased on an average, by about $5 \%$ whereas for shoot the increase was by about $3 \%$ over water control in cv. satabdi. On the contrary, in cv. khitish there was almost negligible increase in growth both in root and shoot over control. However, under $10 \mu \mathrm{M}, 20 \mu \mathrm{M}$ and $50 \mu \mathrm{M}$ selenate treatments, the root lengths were

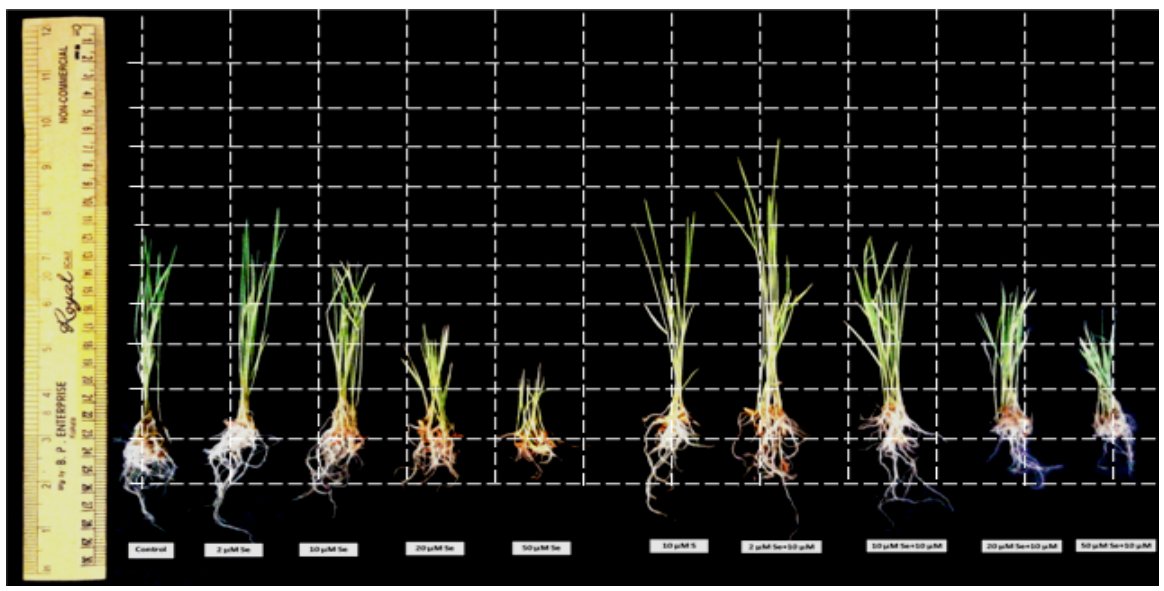

(a)

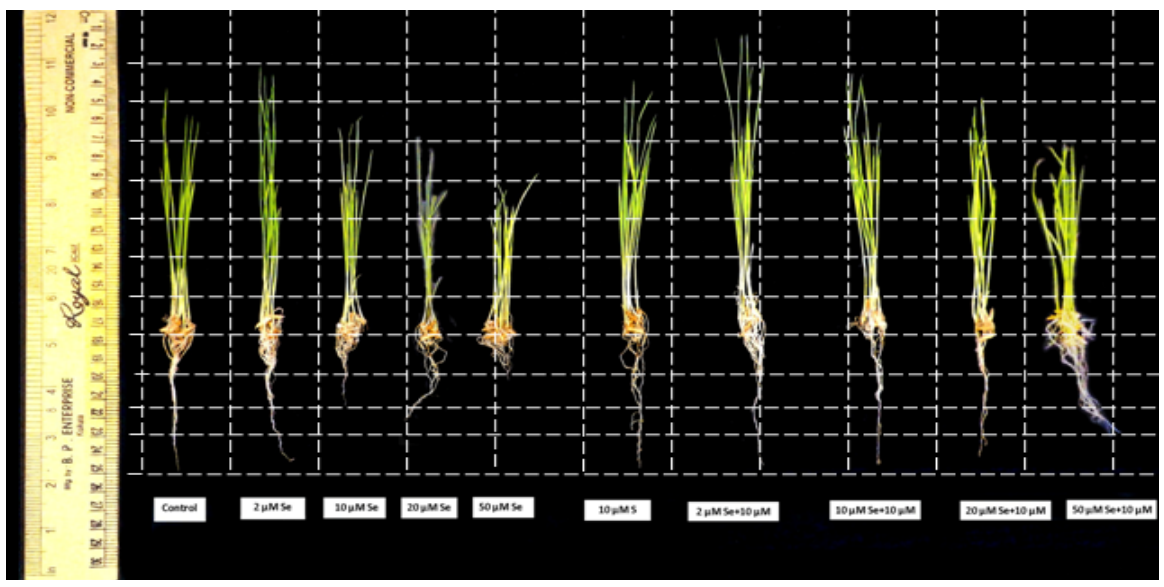

(b) 


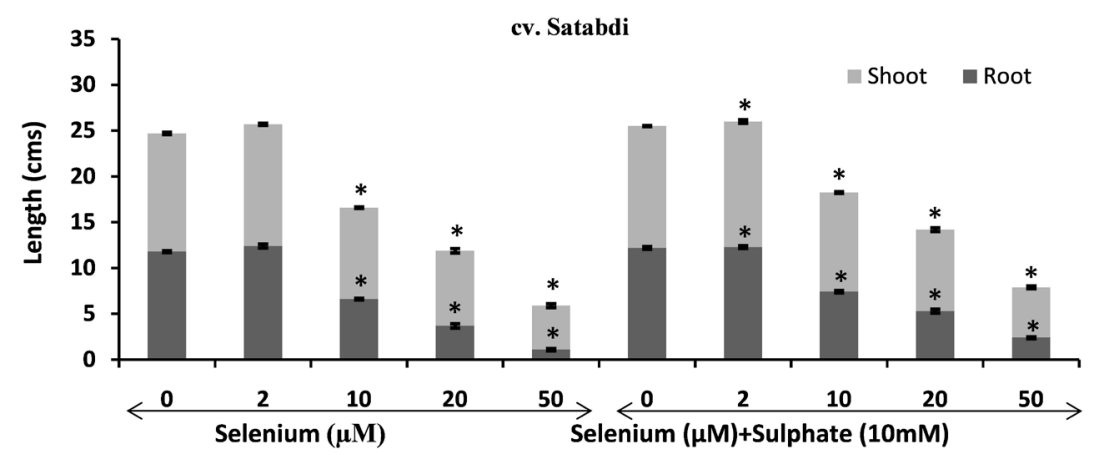

(c)

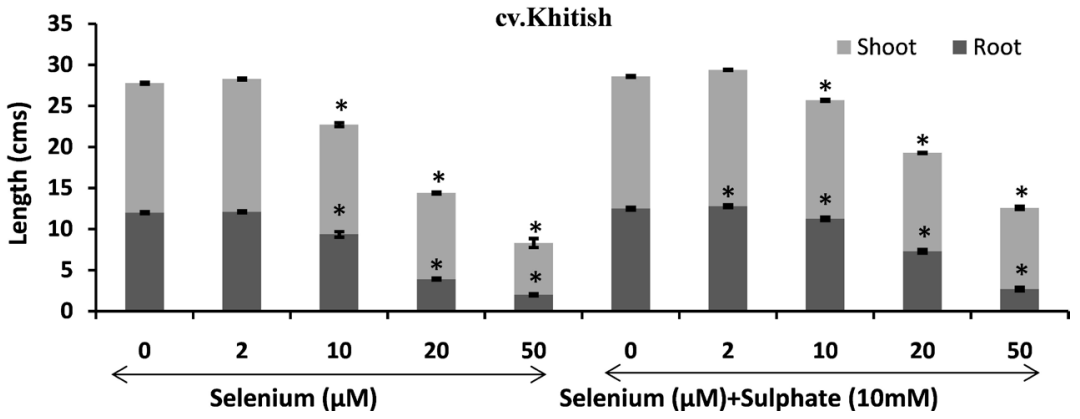

(d)

Figure 1. (a) Effect of various concentrations of selenate and/or sulphate (10 mM) applied either alone or in their combination on the growth of rice (cv. Satabdi) seedlings. (b) Effect of various concentrations of selenate and/or sulphate $(10 \mathrm{mM})$ applied either alone or in their combination on the growth of rice (cv. Khitish) seedlings. (c) Effect of various concentrations of selenate and/or sulphate $(10 \mathrm{mM})$ applied either alone or in their combination on the growth of rice (cv. satabdi) seedlings. Values are the mean $\pm \mathrm{SE}$ of three repeats with two replicas in each treatment, ${ }^{*}$ indicates statistically significant at $p$ $\leq 0.05$ respectively compared to control. (d) Effect of various concentrations of selenate and/or sulphate $(10 \mathrm{mM})$ applied either alone or in their combination on the growth of rice (cv. khitish) seedlings. Values are the mean \pm SE of three repeats with two replicas in each treatment, ${ }^{*}$ indicates statistically significant at $\mathrm{p} \leq 0.05$ respectively compared to control.

reduced significantly on an average, by about $44 \%, 69 \%, 91 \%$ in $\mathrm{cv}$. satabdi and by about $22 \%, 68 \%, 83 \%$ in cv. khitish respectively over water control. Decrease in shoot lengths by about 23\%, 36\%, 63\% in cv. satabdi and about $15 \%, 34 \%$, $60 \%$ in $\mathrm{cv}$. khitish also occurred under similar concentrations respectively over control.

Application of sulphate $(10 \mathrm{mM})$ with $2 \mu \mathrm{M}$ selenate ameliorated the effect caused by selenate alone and increased root lengths of both cv. satabdi and cv. khitish on an average, by about $4 \%$ and $7 \%$ respectively over control. However, the margin of inhibitory effect was narrowed down in root on an average, by about $37 \%, 55 \%, 80 \%$ in cv. satabdi and by about 6\%, 39\%, 78\% in cv. khitish under $10 \mu \mathrm{M}, 20 \mu \mathrm{M}$ and $50 \mu \mathrm{M}$ selenate and $(10 \mathrm{mM})$ sulphate treatments over control. Similarly, under $2 \mu \mathrm{M}$ selenate and sulphate treatment, the shoot length increased by about $6 \%$ in cv. satabdi and $5 \%$ in cv. khitish with respect to control. However, the shoot length decreased by about $16 \%, 31 \%$, and $57 \%$ in $\mathrm{cv}$. 
satabdi and by about $9 \%, 24 \%$, and $37 \%$ in cv. khitish under $10 \mu \mathrm{M}, 20 \mu \mathrm{M}$ and $50 \mu \mathrm{M}$ selenate and $(10 \mathrm{mM})$ sulphate treatments respectively over water control. Therefore, the inhibitory effects observed in shoots of test seedlings treated with combined solutions of selenate and sulphate is less compared to those treated with selenate alone in both cultivars (Figure 1(c) and Figure 1(d)).

\subsection{Effect on Water Content}

The water content showed a dose dependent effect of selenate on the test seedlings. At $2 \mu \mathrm{M}$ selenium, water content increased on an average, by about $2 \%$ in the test seedlings of both cultivars. Application of $10 \mu \mathrm{M}, 20 \mu \mathrm{M}$ and $50 \mu \mathrm{M}$ selenate reduced the water content by about $3 \%, 9 \%, 38 \%$ in $\mathrm{cv}$. satabdi and by about $12 \%, 13 \%, 19 \%$ in $\mathrm{cv}$. khitish respectively over control.

The water content increased on an average by about $5 \%$ in $2 \mu \mathrm{M}$ selenate and sulphate treated test seedlings of both cultivars. Addition of sulphate together with higher concentrations of selenate narrowed down the inhibitory effect on water content of the rice seedlings. Co-application of $10 \mathrm{mM}$ sulphate and 10 $\mu \mathrm{M}, 20 \mu \mathrm{M}$ and $50 \mu \mathrm{M}$ selenate reduced the water content by about $1 \%, 9 \%, 27 \%$ in cv. satabdi and by about $4 \%, 9 \%, 16 \%$ in cv. khitish respectively over water control (Figure 2).

\subsection{Effect on Pigments}

Treatment with $2 \mu \mathrm{M}$ selenate enhanced chl a and chl b contents by about $8 \%$ and $13 \%$, while total chlorophyll contents increased by about $9 \%$ in cv. satabdi. On the other hand, in $2 \mu \mathrm{M}$ selenate treated seedlings of cv. khitish, an increment of about $3 \%$ and $12 \%$ in chl a and chl b contents respectively were noted along with $5 \%$ increase in total chlorophyll contents over control. At higher selenate doses both chl a and chl b levels linearly decreased with increase in selenate concentrations in both the test cultivars. Chl a contents decreased by about $8 \%$, $28 \%$ and $45 \%$ in cv. satabdi and by about $18 \%, 23 \%$ and $26 \%$ in cv. khitish under 10 $\mu \mathrm{M}, 20 \mu \mathrm{M}$ and $50 \mu \mathrm{M}$ selenate treatments respectively. The chl b contents also

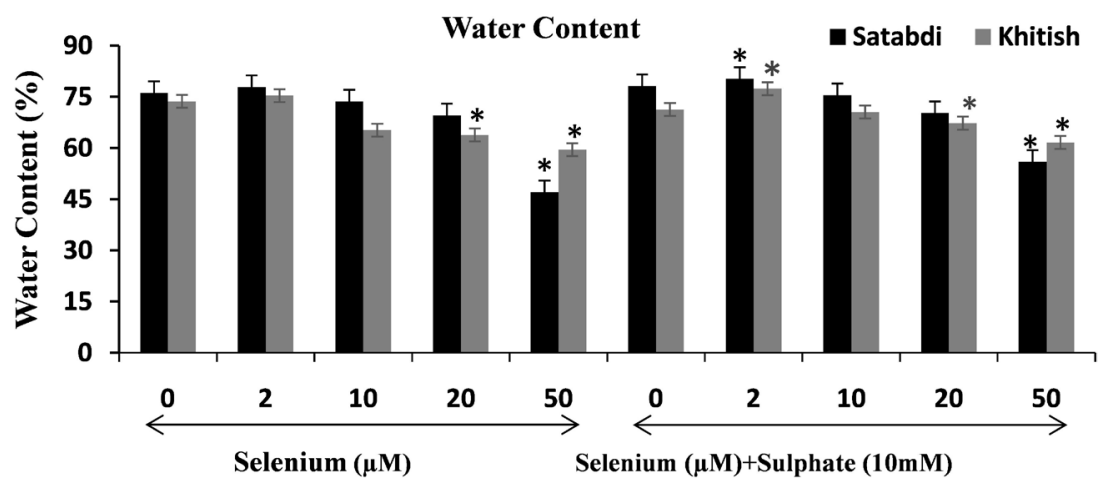

Figure 2. Effect of various concentrations of selenate and/or sulphate (10 mM) applied either alone or in their combination on the water content of rice (cv. satabdi \& cv. khitish) seedlings. Values are the mean $\pm \mathrm{SE}$ of three repeats with two replicas in each treatment, ${ }^{*}$ indicates statistically significant at $\mathrm{p} \leq 0.05$ respectively compared to control. 
declined under similar treatments by about $6 \%, 25 \%$ and $38 \%$ in cv. satabdi and by about $6 \%, 18 \%$ and $29 \%$ in cv. khitish respectively over control. As a result, under $10 \mu \mathrm{M}, 20 \mu \mathrm{M}$ and $50 \mu \mathrm{M}$ selenate treatment, the inhibitory effect on total chlorophyll gradually increased in cv. satabdi seedlings by about $7 \%, 23 \%$ and $43 \%$ and in cv. khitish by about $8 \%, 13 \%$ and $23 \%$ respectively over water control (Table 1 and Table 2).

Co-application of selenate along with sulphate significantly ameliorated the

Table 1. Effect of selenate and/or sulphate on pigment contents in twenty one days old rice (cv. Satabdi) seedlings.

\begin{tabular}{|c|c|c|c|c|c|c|}
\hline Treatment & $\begin{array}{l}\text { Chlorophyll a } \\
\left(\mathrm{mg} \cdot \mathrm{g}^{-1} \mathrm{f} \mathrm{w}\right)\end{array}$ & $\begin{array}{l}\text { Chlorophyll b } \\
\left(\mathrm{mg} \cdot \mathrm{g}^{-1} \mathrm{fw}\right)\end{array}$ & $\begin{array}{l}\text { Total Chlorophyll } \\
\left(\mathrm{mg} \cdot \mathrm{g}^{-1} \mathrm{f} \mathrm{w}\right)\end{array}$ & $\begin{array}{c}\text { Fluorescence } \\
\text { Intensity }\end{array}$ & $\begin{array}{c}\text { Carotene } \\
\left(\mathrm{A}_{425} \mathrm{~g}^{-1} \mathrm{f} \mathrm{w}\right)\end{array}$ & $\begin{array}{l}\text { Xanthophyll } \\
\left(\mathrm{A}_{450} \mathrm{~g}^{-1} \mathrm{f} \text { w) }\right.\end{array}$ \\
\hline Control & $0.40 \pm 0.05$ & $0.16 \pm 0.06$ & $0.56 \pm 0.05$ & $555.0 \pm 2.73$ & $0.38 \pm 0.06$ & $0.37 \pm 0.04$ \\
\hline \multicolumn{7}{|l|}{ Selenate } \\
\hline $2 \mu \mathrm{M}$ & $0.43 \pm 0.04$ & $0.18 \pm 0.04$ & $0.61 \pm 0.04$ & $600.0 \pm 2.81$ & $0.40 \pm 0.04$ & $0.39 \pm 0.05$ \\
\hline $10 \mu \mathrm{M}$ & $0.37 \pm 0.04$ & $0.15 \pm 0.05$ & $0.52 \pm 0.05$ & $480.3^{*} \pm 2.80$ & $0.36 \pm 0.06$ & $0.33 \pm 0.06$ \\
\hline $20 \mu \mathrm{M}$ & $0.29^{*} \pm 0.05$ & $0.12^{\star} \pm 0.06$ & $0.43^{*} \pm 0.06$ & $440.0^{*} \pm 2.74$ & $0.36 \pm 0.04$ & $0.31 \pm 0.04$ \\
\hline $50 \mu \mathrm{M}$ & $0.22^{\star} \pm 0.04$ & $0.10^{*} \pm 0.06$ & $0.32^{\star} \pm 0.05$ & $410.0^{\star} \pm 2.77$ & $0.31^{\star} \pm 0.04$ & $0.30^{\star} \pm 0.06$ \\
\hline Sulphate $(10 \mu \mathrm{M})$ & $0.41 \pm 0.06$ & $0.18 \pm 0.05$ & $0.59 \pm 0.06$ & $545.0 \pm 2.73$ & $0.43 \pm 0.05$ & $0.45 \pm 0.06$ \\
\hline \multicolumn{7}{|l|}{+ Selenate } \\
\hline $2 \mu \mathrm{M}$ & $0.45 \pm 0.05$ & $0.19 \pm 0.06$ & $0.64 \pm 0.06$ & $570.5 \pm 2.62$ & $0.42 \pm 0.04$ & $0.44 \pm 0.06$ \\
\hline $10 \mu \mathrm{M}$ & $0.38 \pm 0.07$ & $0.16 \pm 0.07$ & $0.54 \pm 0.05$ & $550.0 \pm 2.68$ & $0.41 \pm 0.06$ & $0.36 \pm 0.06$ \\
\hline $20 \mu \mathrm{M}$ & $0.32 \pm 0.04$ & $0.14 \pm 0.05$ & $0.47^{\star} \pm 0.05$ & $474.0^{*} \pm 2.67$ & $0.39 \pm 0.05$ & $0.35 \pm 0.05$ \\
\hline $50 \mu \mathrm{M}$ & $0.28^{\star} \pm 0.06$ & $0.13^{*} \pm 0.06$ & $0.41^{\star} \pm 0.06$ & $428.0^{*} \pm 2.70$ & $0.34 \pm 0.05$ & $0.34 \pm 0.05$ \\
\hline
\end{tabular}

Values are the mean \pm SE of three repeats with two replicas in each treatment, ${ }^{*}$ indicates statistically significant at $\mathrm{p} \leq 0.05$ respectively compared to control.

Table 2. Effect of selenate and/or sulphate on pigment contents in twenty one days old rice (cv. Khitish) seedlings.

\begin{tabular}{|c|c|c|c|c|c|c|}
\hline Treatment & $\begin{array}{l}\text { Chlorophyll a } \\
\left(\mathrm{mg} \cdot \mathrm{g}^{-1} \mathrm{f} \mathrm{w}\right)\end{array}$ & $\begin{array}{l}\text { Chlorophyll b } \\
\left(\mathrm{mg} \cdot \mathrm{g}^{-1} \mathrm{f} \mathrm{w}\right)\end{array}$ & $\begin{array}{l}\text { Total Chlorophyll } \\
\left(\mathrm{mg} \cdot \mathrm{g}^{-1} \mathrm{f} \mathrm{w}\right)\end{array}$ & $\begin{array}{l}\text { Fluorescence } \\
\text { Intensity }\end{array}$ & $\begin{array}{c}\text { Carotene } \\
\left(\mathrm{A}_{425} \mathrm{~g}^{-1} \mathrm{f} \mathrm{w}\right)\end{array}$ & $\begin{array}{l}\text { Xanthophyll } \\
\left(A_{450} g^{-1} f_{w}\right)\end{array}$ \\
\hline Control & $0.39 \pm 0.04$ & $0.17 \pm 0.10$ & $0.56 \pm 0.04$ & $525.8 \pm 2.82$ & $0.51 \pm 0.03$ & $0.45 \pm 0.04$ \\
\hline \multicolumn{7}{|l|}{ Selenate } \\
\hline $2 \mu \mathrm{M}$ & $0.40 \pm 0.06$ & $0.19 \pm 0.12$ & $0.59 \pm 0.04$ & $530.0 \pm 2.79$ & $0.48 \pm 0.06$ & $0.43 \pm 0.05$ \\
\hline $10 \mu \mathrm{M}$ & $0.32 \pm 0.05$ & $0.16 \pm 0.12$ & $0.48 \pm 0.05$ & $490.0 \pm 2.73$ & $0.44 \pm 0.05$ & $0.38 \pm 0.04$ \\
\hline $20 \mu \mathrm{M}$ & $0.30 \pm 0.06$ & $0.14 \pm 0.10$ & $0.44^{*} \pm 0.04$ & $457.5 \pm 2.80$ & $0.38 \pm 0.07$ & $0.34 \pm 0.06$ \\
\hline $50 \mu \mathrm{M}$ & $0.29^{\star} \pm 0.05$ & $0.12 \pm 0.12$ & $0.41^{*} \pm 0.06$ & $412.5^{\star} \pm 2.76$ & $0.36 \pm 0.06$ & $0.32 \pm 0.06$ \\
\hline Sulphate $(10 \mu \mathrm{M})$ & $0.38 \pm 0.06$ & $0.22 \pm 0.11$ & $0.60 \pm 0.05$ & $515.0 \pm 2.82$ & $0.49 \pm 0.06$ & $0.48 \pm 0.04$ \\
\hline \multicolumn{7}{|l|}{+ Selenate } \\
\hline $2 \mu \mathrm{M}$ & $0.41 \pm 0.06$ & $0.20 \pm 0.13$ & $0.61 \pm 0.06$ & $540.0 \pm 2.71$ & $0.50 \pm 0.05$ & $0.46 \pm 0.04$ \\
\hline $10 \mu \mathrm{M}$ & $0.36 \pm 0.04$ & $0.18 \pm 0.12$ & $0.54 \pm 0.04$ & $510.0 \pm 2.77$ & $0.43 \pm 0.06$ & $0.42 \pm 0.05$ \\
\hline $20 \mu \mathrm{M}$ & $0.33 \pm 0.04$ & $0.15 \pm 0.14$ & $0.48 \pm 0.06$ & $480.0 \pm 2.69$ & $0.38 \pm 0.05$ & $0.37 \pm 0.05$ \\
\hline $50 \mu \mathrm{M}$ & $0.32 \pm 0.04$ & $0.13 \pm 0.13$ & $0.45^{\star} \pm 0.05$ & $440.0^{\star} \pm 2.78$ & $0.37 \pm 0.05$ & $0.36 \pm 0.05$ \\
\hline
\end{tabular}

Values are the mean $\pm \mathrm{SE}$ of three repeats with two replicas in each treatment, ${ }^{*}$ indicates statistically significant at $\mathrm{p} \leq 0.05$ respectively compared to control. 
effect of selenate alone on the test seedlings. Joint treatment with $2 \mu \mathrm{M}$ selenate and sulphate enhanced chl a by about $13 \%$ and chl b by about $19 \%$ in cv. satabdi while in cv. khitish, similar treatment increased the level of chl a and chl b by about $5 \%$ and $18 \%$ respectively over water control. Simultaneous application of sulphate along with $10 \mu \mathrm{M}, 20 \mu \mathrm{M}$ and $50 \mu \mathrm{M}$ concentrations of selenate showed a recovery of inhibition in total chlorophyll contents by about $4 \%, 16 \%$ and $27 \%$ in cv. satabdi and by about $3 \%, 5 \%$ and $7 \%$ in cv. khitish seedlings with respect to control.

The fluorescence intensity (F.I) initially increased on an average by about $4 \%$ in seedlings of both cultivars under $2 \mu \mathrm{M}$ selenate treatments. Subsequently a significant drop in F.I were recorded at $10 \mu \mathrm{M}, 20 \mu \mathrm{M}$ and $50 \mu \mathrm{M}$ selenate treatment which were about $14 \%, 21 \%$ and $26 \%$ respectively in cv. satabdi and about $7 \%, 13 \%$ and $22 \%$ respectively in cv. khitish over control. Combined application of selenate and sulphate mitigated the inhibitory effect on F.I to some degree in the test seedlings. In cv. satabdi, application of $10 \mathrm{mM}$ sulphate along with 10 $\mu \mathrm{M}, 20 \mu \mathrm{M}$ and $50 \mu \mathrm{M}$ selenate narrowed down the inhibitory effect on F.I by about $1 \%, 15 \%$ and $23 \%$ respectively whereas in cv. khitish, the F.I decreased by about $3 \%, 9 \%$ and $16 \%$ respectively over water control.

The Hill Reaction Activity (HRA) was negatively affected with increase in selenate concentration in both test cultivars. The HRA was reduced on an average by about $5 \%$ in the $2 \mu \mathrm{M}$ treated rice seedlings of cv. satabdi and cv. khitish. A linear decline by about $11 \%, 34 \%$ and $42 \%$ in HRA activity were observed in 10 $\mu \mathrm{M}, 20 \mu \mathrm{M}$ and $50 \mu \mathrm{M}$ selenate treated rice seedlings of cv. satabdi with respect to water control. Similar pattern was observed in cv. khitish where the HRA also decreased by about $17 \%, 34 \%$ and $36 \%$ in the said concentrations of selenate over control. However joint application of sulphate and selenate ameliorated the negative effect of selenate alone on Hill Reaction Activity considerably which coincided with its promotive influence on the chlorophyll contents of the test tissue.

Selenium exerted an inhibitory effect on the level of accessory pigments, carotene and xanthophyll in seedlings of cv. satabdi and cv. khitish. At $2 \mu \mathrm{M}$ selenate concentration, both carotene and xanthophyll levels increased by about $5 \%$ in $\mathrm{cv}$. satabdi while in cv. khitish, the level of both the accessory pigments declined on an average by about $5 \%$ with respect to water control. A gradual decline in both carotene and xanthophyll contents at higher concentrations of selenate in both the test cultivars were noted. Carotene contents decreasedby about $5 \%$ under both $10 \mu \mathrm{M}$ and $20 \mu \mathrm{M}$ selenate treatments and by about $13 \%$ under $50 \mu \mathrm{M}$ selenate treatment in cv. satabdi compared to about $14 \%, 26 \%$ and $29 \%$ in $\mathrm{cv}$. khitish seedlings. Xanthophyll contents similarly decreased by about $11 \%, 16 \%$ and $19 \%$ in cv. satabdi and by about $16 \%, 24 \%$ and $29 \%$ in cv. khitish under 10 $\mu \mathrm{M}, 20 \mu \mathrm{M}$ and $50 \mu \mathrm{M}$ selenate treatment respectively. Therefore, selenate treatment affected the chlorophyll contents as well as accessory pigments of cv. satabdi to a greater extent compared to that of $\mathrm{cv}$. khitish.

On application of sulphate along with $2 \mu \mathrm{M}$ selenate, carotene contents increased by about $11 \%$ while xanthophyll contents increased by about $19 \%$ in cv. 
satabdi seedlings over control. However, there was very little change in carotene and xanthophyll levels on seedlings of cv. khitish treated with $2 \mu \mathrm{M}$ selenate and sulphate. Under combined treatments, carotene contents in cv. satabdi increased by $8 \%$ and $3 \%$ under $10 \mu \mathrm{M}$ and $20 \mu \mathrm{M}$ selenate and sulphate treatments respectively over control. The margin of decline in carotene contents was however, narrowed down by about $11 \%$ in $50 \mu \mathrm{M}$ selenate and sulphate treated rice seedlings of $\mathrm{cv}$. satabdi in comparison to the test seedlings treated individually with $50 \mu \mathrm{M}$ selenate. Similarly in cv. khitish, the carotene level declined by about $17 \%, 26 \%$ and $28 \%$ under the said concentrations of selenate and sulphate. Following an identical pattern the xanthophyll contents also declined by about $3 \%$, $5 \%$ and $8 \%$ and by about $7 \%, 18 \%$ and $20 \%$ in cv. satabdi and cv. khitish respectively under combined treatment with sulphate and said concentrations of selenate over control.

\subsection{Effect on Antioxidant Enzymes Activity}

\subsubsection{Superoxide Dismutase (SOD)}

Exogenous application of selenate showed a dose dependent increase in SOD activity in roots and shoots of both cultivars of rice over control. In case of $2 \mu \mathrm{M}$ selenate treatment very little increase in SOD activity were observed in test seedlings of cv. satabdi and cv. khitish over control. Thereafter, the SOD activity in roots increased remarkably by about $69 \%, 144 \%, 147 \%$ and in shoots by about $78 \%, 109 \%, 160 \%$ in $10 \mu \mathrm{M}, 20 \mu \mathrm{M}$ and $50 \mu \mathrm{M}$ selenate treated rice seedlings of cv. satabdi respectively. The enzyme activity also increased significantly by about $75 \%, 145 \%, 150 \%$ in roots and by about $42 \%, 82 \%, 83 \%$ in shoots of cv. khitish respectively over water control (Figure 3(a) and Figure 3(b)).

Administration of sulphate and $2 \mu \mathrm{M}$ selenate together inhibited SOD activity in root and shoot by about $9 \%$ and $4 \%$ in cv. Satabdi and by about $5 \%$ and $33 \%$ in cv. khitish respectively over control. The inhibitory effect was further reduced under $10 \mu \mathrm{M}$ selenate, sulphate treatment by about about $9 \%$ in root and very little in shoots of cv. satabdi. Although in cv. khitish the SOD activity increased at 10 $\mu \mathrm{M}$ selenate, sulphate treatment by about $42 \%$ in root and by about $9 \%$ in shoot, the increment was much less in comparison to seedlings treated with selenate only. Similar trend was observed in cv. satabdi where the rise in SOD activity by about $60 \%$ and $123 \%$ in roots and by about $79 \%$ and $128 \%$ in shoots respectively under the influence of combined $20 \mu \mathrm{M}$ and $50 \mu \mathrm{M}$ selenate and sulphate solutions was less than that observed in seedlings treated with same concentration of selenate alone. The same effect was reflected in cv. khitish where the enhanced enzyme activity of about $42 \%, 89 \%$ and $138 \%$ in roots and about $8 \%, 35 \%$ and $37 \%$ in shoots under $10 \mu \mathrm{M}, 20 \mu \mathrm{M}$ and $50 \mu \mathrm{M}$ selenate and sulphate treatment were less compared to rice seedlings treated with selenate only.

\subsubsection{Catechol Peroxidase (CPX)}

An opposite effect was observed in case of catechol peroxidase (CPX) activity in the test seedlings under the influence of selenate. The enzyme activity decreased 

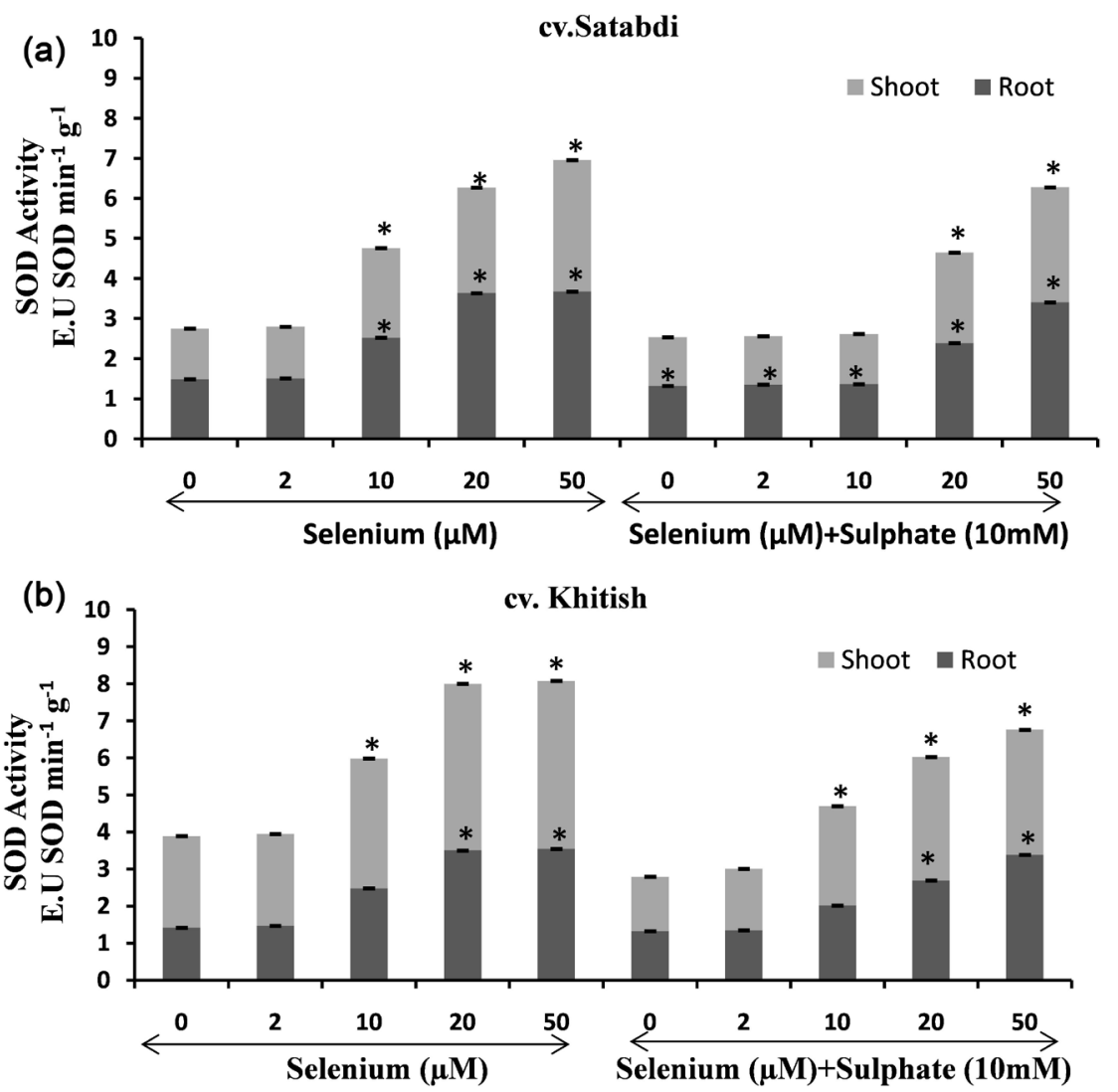

Figure 3. (a) Effect of various concentrations of selenate and/or sulphate (10 mM) applied either alone or in their combination on the SOD activity of rice (cv. satabdi) seedlings. Values are the mean $\pm S E$ of three repeats with two replicas in each treatment, *indicates statistically significant at $\mathrm{p} \leq 0.05$ respectively compared to control. (b) Effect of various concentrations of selenate and/or sulphate $(10 \mathrm{mM})$ applied either alone or in their combination on the SOD activity of rice (cv. khitish) seedlings. Values are the mean \pm SE of three repeats with two replicas in each treatment, ${ }^{*}$ indicates statistically significant at $\mathrm{p} \leq 0.05$ respectively compared to control.

with increase in concentrations of selenate in roots and shoots of both test cultivars. The activity of CPX under $2 \mu \mathrm{M}$ selenate treatment decreased in root and shoot by about $36 \%$ and $8 \%$ in cv. satabdi and by about $7 \%$ in root and very little in shoot of cv. khitish over control. Exposure to $10 \mu \mathrm{M}, 20 \mu \mathrm{M}$ and $50 \mu \mathrm{M}$ selenate inhibited enzyme activity by about $18 \%, 44 \%$ and $60 \%$ in roots and $22 \%$, $24 \%$ and $25 \%$ in shoots of $\mathrm{cv}$. satabdi and by about $10 \%, 47 \%$ and $55 \%$ in roots and very little in shoots of cv. khitish respectively over control (Figure 4(a) and Figure 4(b)).

Co-application of $10 \mathrm{mM}$ sulphate and selenate inhibited CPX activity in test seedlings but the inhibitory effect was less pronounced than observed in seedlings treated with selenate alone. Factorial combination of $2 \mu \mathrm{M}$ selenate and sulphate reduced enzyme activity by about $35 \%$ and $22 \%$ in root and shoot respectively in cv. Satabdi. However, under same treatment, the enzyme activity decreased by about $3 \%$ in roots and increased very little in shoots of cv. khitish over water control. Further in cv. satabdi the CPX activity declined on an average 

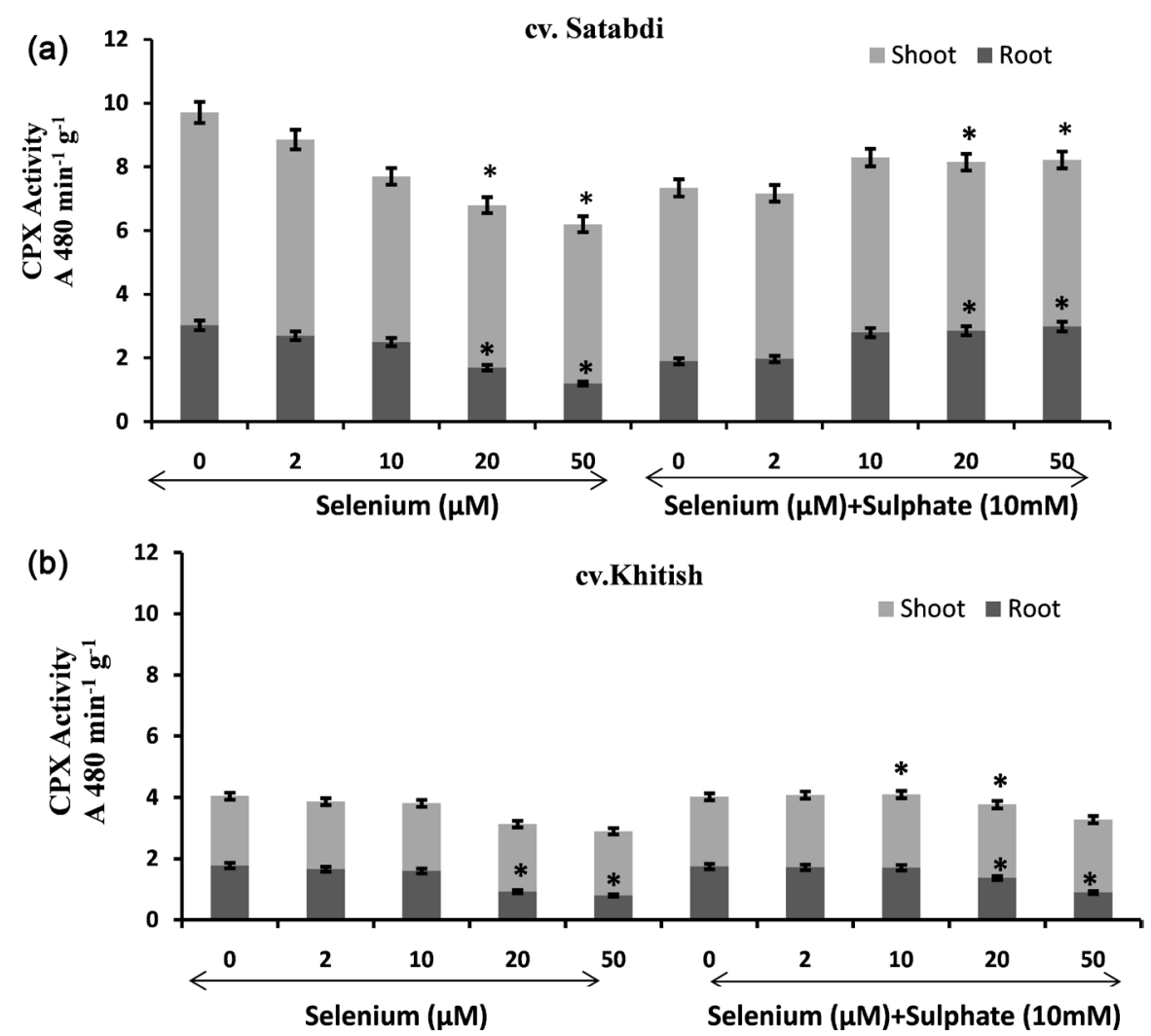

Figure 4. (a) Effect of various concentrations of selenate and/or sulphate (10 mM) applied either alone or in their combination on the CPX activity of rice (cv. satabdi) seedlings. Values are the mean \pm SE of three repeats with two replicas in each treatment, ${ }^{*}$ indicates statistically significant at $\mathrm{p} \leq 0.05$ respectively compared to control. (b) Effect of various concentrations of selenate and/or sulphate $(10 \mathrm{mM})$ applied either alone or in their combination on the CPX activity of rice (cv. khitish) seedlings. Values are the mean \pm SE of three repeats with two replicas in each treatment, ${ }^{*}$ indicates statistically significant at $\mathrm{p} \leq 0.05$ respectively compared to control.

by about $5 \%$ in roots and $20 \%$ in shoots of $10 \mu \mathrm{M}, 20 \mu \mathrm{M}$ and $50 \mu \mathrm{M}$ selenate and sulphate treated test seedlings. On the contrary the enzyme activity decreased by about $4 \%, 23 \%$ and $49 \%$ in roots but increased on an average by about $5 \%$ in shoots of $\mathrm{cv}$. khitish with respect to control.

\subsubsection{Catalase (CAT)}

Selenate exerted a variable effect on the catalase activity in roots and shoots of the test seedlings. In both the cultivars, the catalase activity in roots decreased with increasing concentrations of selenate. However, at $2 \mu \mathrm{M}$ selenate treatment the catalase activity increased by about $14 \%$ and $54 \%$ in roots and shoots of $\mathrm{cv}$. satabdi respectively over control. Under same concentration of selenate, very little increment in the enzyme activity occurred in roots while it increased by about $28 \%$ in shoots of $\mathrm{cv}$. khitish with respect to control. Thereafter application of $10 \mu \mathrm{M}, 20 \mu \mathrm{M}$ and $50 \mu \mathrm{M}$ selenate inhibited catalase activity by about $6 \%, 28 \%$ and $54 \%$ in roots and initially increased by about $15 \%$ and then decreased by about $4 \%$ and $14 \%$ in shoots of cv.satabdi respectively. Similar trend was ob- 
served in cv. khitish where the enzyme activity gradually decreased by about $6 \%$, $17 \%$ and $35 \%$ in roots under $10 \mu \mathrm{M}, 20 \mu \mathrm{M}$ and $50 \mu \mathrm{M}$ selenate treatment. However, in shoots of cv. khitish, the catalase activity increased by about $28 \%$ and $8 \%$ under $10 \mu \mathrm{M}$ and $20 \mu \mathrm{M}$ selenate treatment respectively followed by significant decrease of about $25 \%$ under $50 \mu \mathrm{M}$ selenate treatment with respect to control (Figure 5(a) and Figure 5(b)).

Co-application of sulphate and selenate increased catalase activity in both test cultivars. The rice seedlings treated with $2 \mu \mathrm{M}$ selenate and sulphate registered an increase in catalase activity by about $18 \%$ in roots and by about $70 \%$ in shoots of cv. satabdi. However, under same concentration the catalase activity decreased by about $7 \%$ in roots but increased by about $28 \%$ in shoots of cv. khitish over control. Exposure to combined $10 \mu \mathrm{M}$ selenate and sulphate increased catalase activity in roots and shoots by about $22 \%$ and $70 \%$ in cv. satabdi and by about $10 \%$ and $42 \%$ in cv. khitish respectively. This positive trend was altered under joint application of $20 \mu \mathrm{M}$ and $50 \mu \mathrm{M}$ selenate and sulphate where the enzyme activity decreased slightly on an average in roots and increased on an
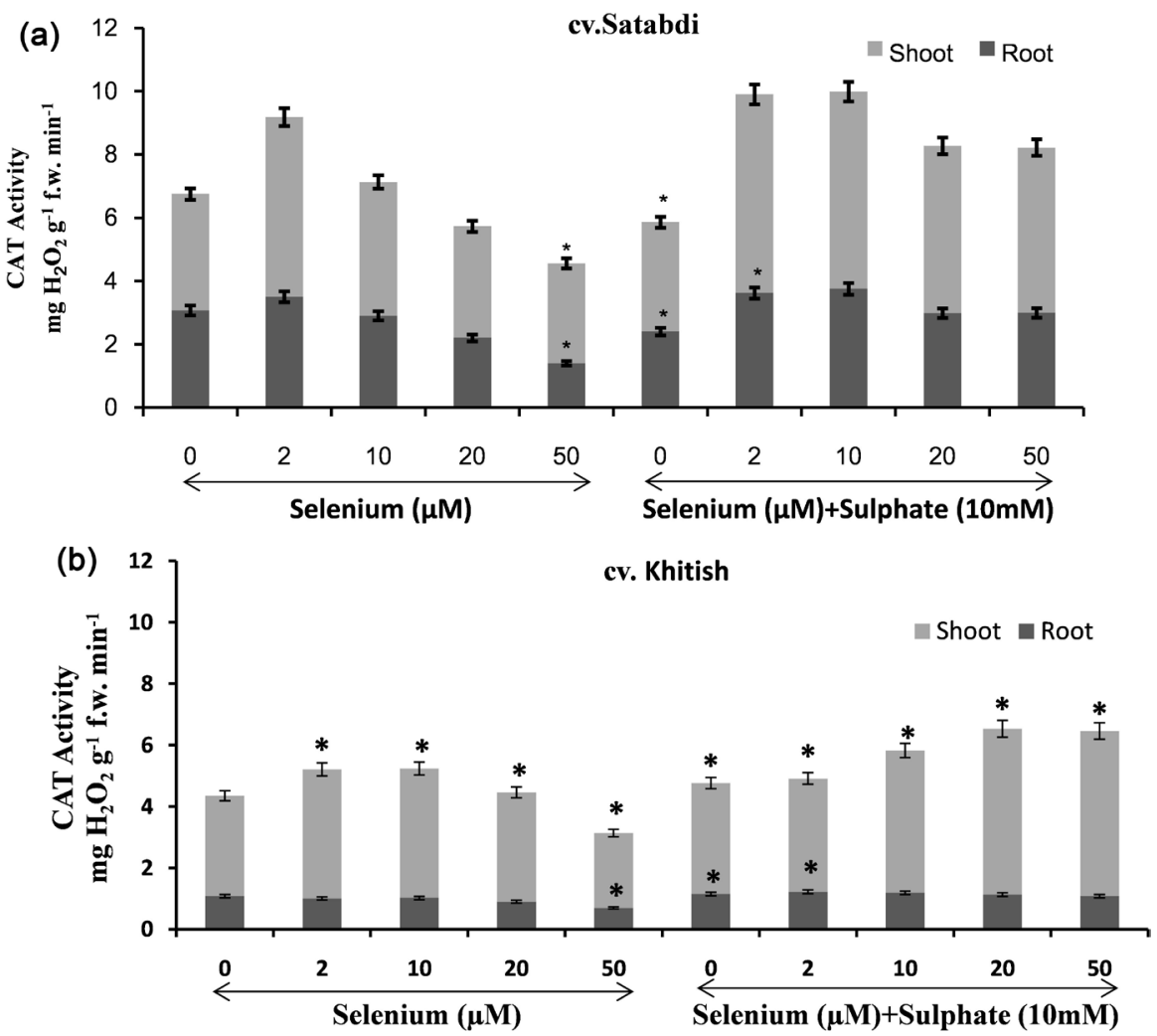

Figure 5. (a) Effect of various concentrations of selenate and/or sulphate $(10 \mathrm{mM})$ applied either alone or in their combination on the CAT activity of rice (cv. satabdi) seedlings. Values are the mean \pm SE of three repeats with two replicas in each treatment, *indicates statistically significant at $\mathrm{p} \leq 0.05$ respectively compared to control. (b) Effect of various concentrations of selenate and/or sulphate $(10 \mathrm{mM})$ applied either alone or in their combination on the CAT activity of rice (cv. khitish) seedlings. Values are the mean \pm SE of three repeats with two replicas in each treatment, ${ }^{*}$ indicates statistically significant at $\mathrm{p} \leq 0.05$ respectively compared to control. 
average by about $43 \%$ in shoots of cv. satabdi. In cv. khitish under same condition the negligible enhancement in enzyme activity in roots were countered by significant increase on an average by about $65 \%$ in shoots over water control.

\subsection{Effect on Oxidative Stress Markers}

\subsubsection{Effect on Proline Content}

Selenium treatment caused a significant increase in proline contents in root and shoot of test seedlings over water control. The proline contents decreased in 2 $\mu \mathrm{M}$ selenate treated seedlings by about $17 \%$ and $9 \%$ in root and shoot of $\mathrm{cv}$. satabdi and by about $3 \%$ and $20 \%$ in root and shoot of cv.khitish respectively. Thereafter, the proline contents increased considerably with increase in concentrations of selenate. Maximum increase was observed in $50 \mu \mathrm{M}$ selenate treatment where it increased by about $58 \%$ and $86 \%$ in root and shoot of cv. satabdi and by about $45 \%$ and $48 \%$ in root and shoot of cv.khitish respectively over water control (Figure 6(a) and Figure 6(b)).

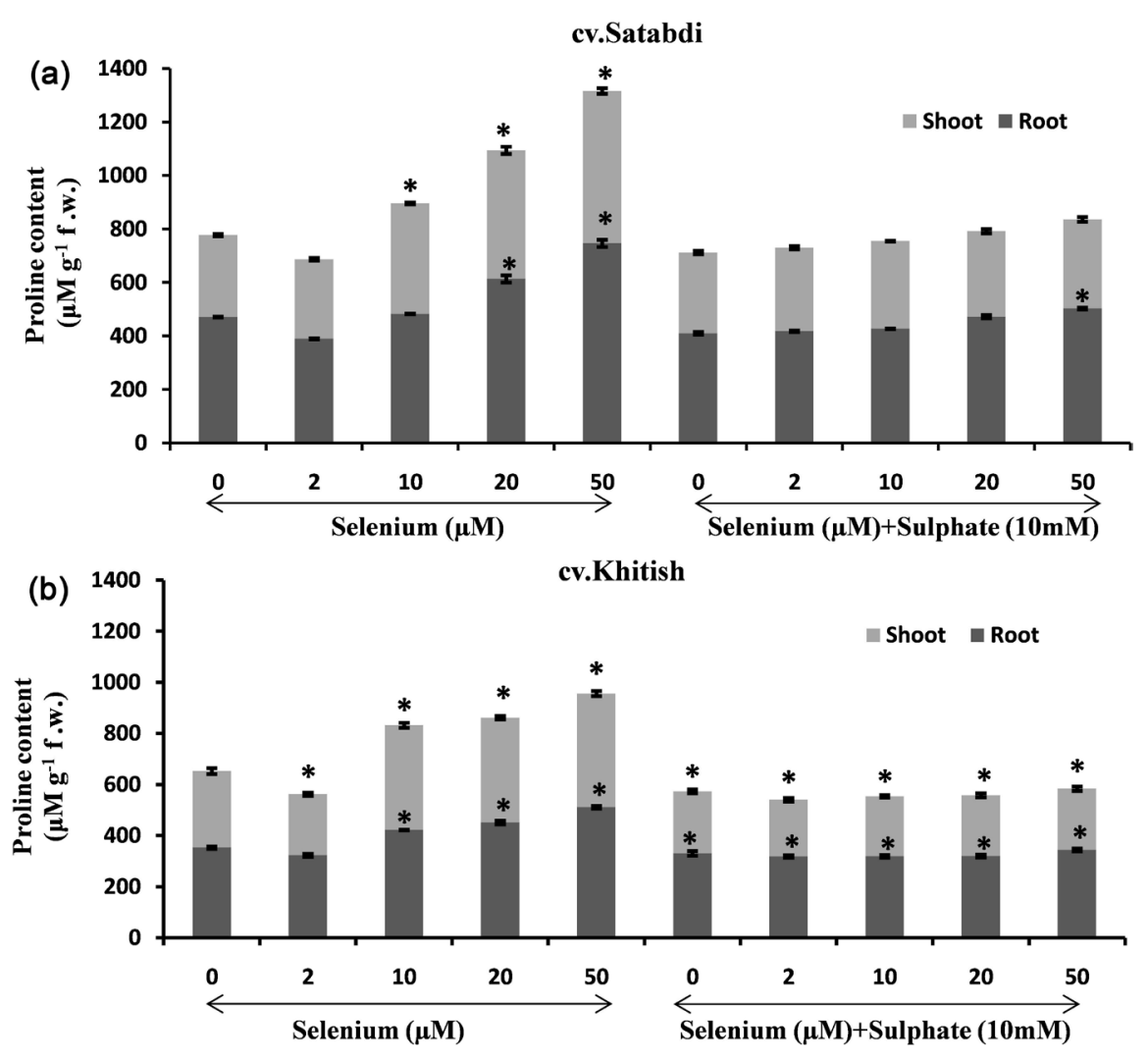

Figure 6. (a) Effect of various concentrations of selenate and/or sulphate $(10 \mathrm{mM})$ applied either alone or in their combination on the proline content of rice (cv. satabdi) seedlings. Values are the mean $\pm \mathrm{SE}$ of three repeats with two replicas in each treatment, *indicates statistically significant at $\mathrm{p} \leq 0.05$ respectively compared to control. (b) Effect of various concentrations of selenate and/or sulphate $(10 \mathrm{mM})$ applied either alone or in their combination on the proline content of rice (cv. khitish) seedlings. Values are the mean \pm SE of three repeats with two replicas in each treatment, ${ }^{*}$ indicates statistically significant at $\mathrm{p} \leq 0.05$ respectively compared to control. 
Simultaneous treatment with selenium and $10 \mathrm{mM}$ sulphate declined proline contents in root and shoot of both the rice cultivars. Though application of $2 \mu \mathrm{M}$ selenate and sulphate reduced proline contents by about $11 \%$ in root of $\mathrm{cv}$. satabdi, small increment occurred in shoot over water control. On the contrary in $2 \mu \mathrm{M}$ selenate and sulphate treated $\mathrm{cv}$. khitish, the proline contents decreased by about $10 \%$ in root and doubly in shoot with respect to control. The proline contents which decreased by about $9 \%$ in root registered an increase by about $7 \%$ in shoot of $10 \mu \mathrm{M}$ selenium and sulphate treated test seedlings of cv. satabdi. Further combined application of $20 \mu \mathrm{M}, 50 \mu \mathrm{M}$ selenate along with sulphate increased proline contents on an average, by about $3 \%$ in root and $6 \%$ in shoot of cv.. satabdi which was much less in comparison to treatment with selenate only. In cv. khitish the proline contents were inhibited on an average by about $7 \%$ in roots and $21 \%$ in shoots of test seedlings exposed to $10 \mu \mathrm{M}, 20 \mu \mathrm{M}$ and $50 \mu \mathrm{M}$ selenate along with sulphate over water control.

\subsubsection{Effect of on Total Peroxide $\left(\mathrm{H}_{2} \mathrm{O}_{2}\right)$ Content}

Selenium exposure caused a steep increase in total peroxide contents in root and shoot of both cultivars. A stimulatory effect occurred in $2 \mu \mathrm{M}$ selenate treated rice seedlings of cv. satabdi where the total peroxide contents increased on an average by about $12 \%$ with respect to control. The total peroxide contents further increased by about $43 \%, 49 \%$ and $73 \%$ in roots and by about $46 \%, 63 \%$ and $68 \%$ in shoots of cv. satabdi under $10 \mu \mathrm{M}, 20 \mu \mathrm{M}$ and $50 \mu \mathrm{M}$ selenate treatment respectively. Although the total peroxide level in roots of cv. khitish was initially inhibited by about $10 \%$ under $2 \mu \mathrm{M}$ selenate treatment, it registered a stimulatory effect of about $8 \%$ in shoot under same concentration. The level of total peroxide also increased by about $2 \%, 33 \%$ and $39 \%$ in roots and by about $21 \%$, $40 \%$ and $50 \%$ in shoots of $10 \mu \mathrm{M}, 20 \mu \mathrm{M}$ and $50 \mu \mathrm{M}$ selenate treated test seedlings of cv. khitish respectively over water control (Figure 7(a) and Figure $7(\mathrm{~b}))$.

Co-application of sulphate and selenate altered the effect caused by selenate treatment alone and decreased the total peroxide contents in both test cultivars. Exposure to $2 \mu \mathrm{M}$ selenate and sulphate increased the total peroxide contents in root and shoot by about $12 \%$ and $9 \%$ respectively in cv. satabdi whereas in $\mathrm{cv}$. khitish it diminished by about $9 \%$ in root but increased by equal amount in shoot over water control. The total peroxide recorded very little increase in its content in root whereas it increased on an average, by about $29 \%$ in shoot of $\mathrm{cv}$. satabdi under $10 \mu \mathrm{M}$ and $20 \mu \mathrm{M}$ selenate and sulphate treatment. Similarly in cv. khitish the total peroxide contents increased by about $7 \%$ and $18 \%$ in shoot but decreased by about $30 \%$ and $23 \%$ in root under $10 \mu \mathrm{M}$ and $20 \mu \mathrm{M}$ selenate and sulphate treatment respectively. The total peroxide contents also increased in root and shoot by about $24 \%$ and $42 \%$ in cv. satabdi and by about $11 \%$ and $32 \%$ in cv. khitish respectively when jointly treated with $50 \mu \mathrm{M}$ selenate and $10 \mathrm{mM}$ sulphate but the increment was much less compared to treatment with $50 \mu \mathrm{M}$ selenate alone. 

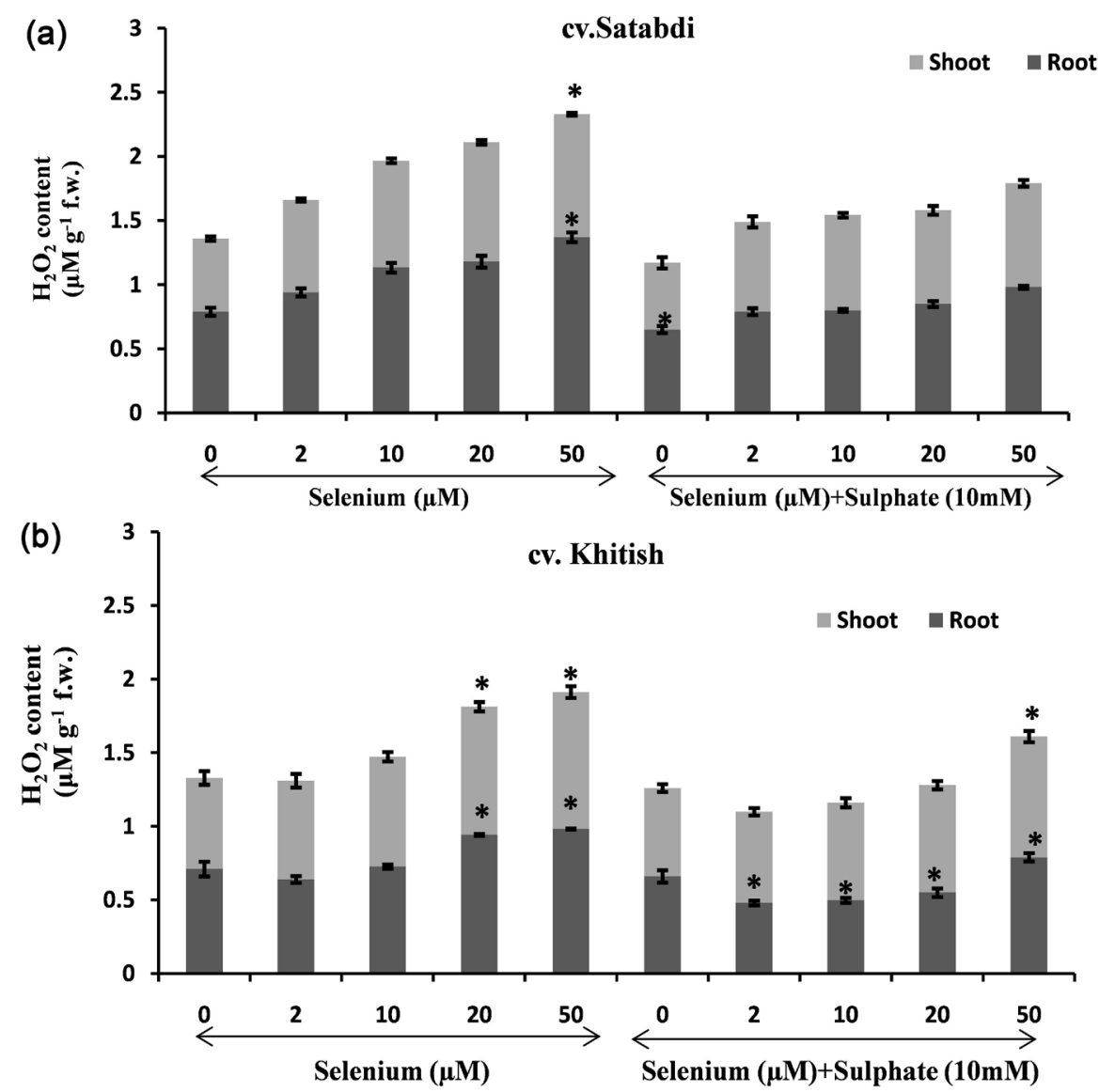

Figure 7. (a) Effect of various concentrations of selenate and/or sulphate (10 mM) applied either alone or in their combination on the $\mathrm{H}_{2} \mathrm{O}_{2}$ content of rice (cv. satabdi) seedlings. Values are the mean \pm SE of three repeats with two replicas in each treatment, *indicates statistically significant at $\mathrm{p} \leq 0.05$ respectively compared to control. (b) Effect of various concentrations of selenate and/or sulphate $(10 \mathrm{mM})$ applied either alone or in their combination on the $\mathrm{H}_{2} \mathrm{O}_{2}$ content of rice (cv. khitish) seedlings. Values are the mean $\pm \mathrm{SE}$ of three repeats with two replicas in each treatment, ${ }^{*}$ indicates statistically significant at $\mathrm{p} \leq 0.05$ respectively compared to control.

\subsubsection{Effect on Malondialdehyde (MDA) Content}

Selenate at low concentration acted as an antioxidant, inhibiting lipid peroxidation, whereas at higher concentrations, it acted as a pro-oxidant, enhancing lipid peroxidation as measured by the accumulation of malondialdehyde contents. Low concentration of selenate $(2 \mu \mathrm{M})$ diminished lipid peroxidation on an average by about $14 \%$ in roots and very little in shoots of cv. satabdi and by about $13 \%$ in roots and $5 \%$ in shoots of $\mathrm{cv}$. khitish with respect to water control.The decrease in MDA contents were more pronounced in roots than in shoots of both cultivars. In cv.satabdi, loss of MDA content followed a descending order where it initially decreased very little at $10 \mu \mathrm{M}$ selenate, then increased by about $10 \%$ and $23 \%$ in roots of $20 \mu \mathrm{M}$ and $50 \mu \mathrm{M}$ selenate treated rice seedlings respectively over control.In shoot the MDA level linearly increased by about $11 \%, 17 \%$ and $28 \%$ under $10 \mu \mathrm{M}, 20 \mu \mathrm{M}$ and $50 \mu \mathrm{M}$ of selenate treatment in cv.satabdi. The MDA contents of roots and shoots of $\mathrm{cv}$. khitish declined by about $10 \%$ and $4 \%$ 
respectively under $10 \mu \mathrm{M}$ selenate treatment whereas very little or negligible effect was observed in $20 \mu \mathrm{M}$ selenate treated rice seedlings of cv. khitish. However, the MDA contents registered a dramatic increase by about $33 \%$ and $24 \%$ in roots and shoots respectively of same cultivar under $50 \mu \mathrm{M}$ selenate treatment (Figure 8(a) and Figure 8(b)).

Combined selenate and sulphate treatment ameliorated the effect of selenate only and apprehended the rise in MDA level in seedlings of both test cultivars. Joint application of $2 \mu \mathrm{M}$ selenate and sulphate significantly decreased MDA level in root and shoot by about $25 \%$ and $6 \%$ in cv. satabdi and by about $15 \%$ and $6 \%$ in cv. khitish respectively. Further the increase in MDA level initially narrowed very little under combined $10 \mu \mathrm{M}$ selenate-sulphate treatment but it increased by about $10 \%$ and $16 \%$ under $20 \mu \mathrm{M}$ and $50 \mu \mathrm{M}$ selenate-sulphate treatment respectively in roots of cv.satabdi. Similar trend occurred under same condition in roots of $\mathrm{cv}$. khitish where the MDA level were enhanced by about $9 \%, 12 \%$ and $14 \%$ respectively over water control.Under $10 \mu \mathrm{M}, 20 \mu \mathrm{M}$ and 50
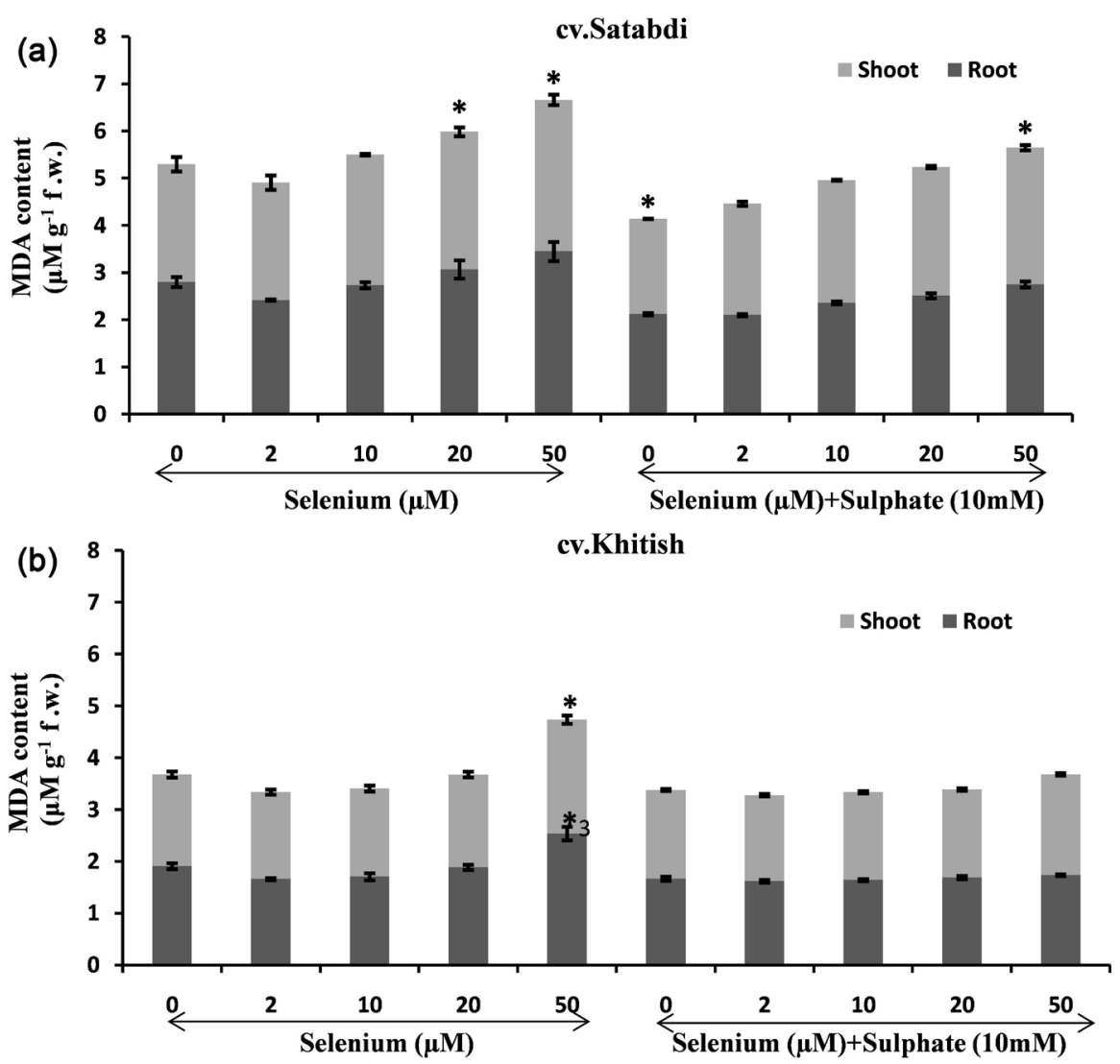

Figure 8. (a) Effect of various concentrations of selenate and/or sulphate (10 mM) applied either alone or in their combination on the MDA content of rice (cv. satabdi) seedlings. Values are the mean \pm SE of three repeats with two replicas in each treatment, ${ }^{\star}$ indicates statistically significant at $\mathrm{p} \leq 0.05$ respectively compared to control. (b) Effect of various concentrations of selenate and/or sulphate $(10 \mathrm{mM})$ applied either alone or in their combination on the MDA content of rice (cv. khitish) seedlings. Values are the mean \pm SE of three repeats with two replicas in each treatment, *indicates statistically significant at $\mathrm{p} \leq 0.05$ respectively compared to control. 
$\mu \mathrm{M}$ selenate and $10 \mathrm{mM}$ sulphate treatments the lipid peroxidation contents also increased by about $4 \%, 9 \%$ and $16 \%$ in shoots of cv. satabdi and decreased initially by about $4 \%$ and $3 \%$ and then increased by about $10 \%$ in shoots of cv. khitish respectively over control.

\subsection{Effect on Starch and Carbohydrate Contents}

\subsubsection{Starch}

In both root and shoot of the test seedlings, the starch content decreased with increasing selenate treatment. Initially at $2 \mu \mathrm{M}$ selenate concentration the starch level increased by about $23 \%$ and $11 \%$ in root and shoot of $\mathrm{cv}$. satabdi and on an average by about $5 \%$ in seedlings of $\mathrm{cv}$. khitish respectively over control.Under $10 \mu \mathrm{M}, 20 \mu \mathrm{M}$ and $50 \mu \mathrm{M}$ selenate treatment, the starch level gradually decreased by about $13 \%, 18 \%$ and $22 \%$ in roots and by about $5 \%, 11 \%$ and $12 \%$ in shoots of cv. satabdi respectively. In cv. khitish, the starch content also decreased by about $10 \%, 12 \%$ and $15 \%$ in roots and by about $7 \%, 9 \%$ and $11 \%$ in shoots under similar condition with respect to control (Figure 9(a) and Figure 9(b)).

Joint application of said concentrations of selenate with $10 \mathrm{mM}$ sulphate altered the effect caused by selenate alone in the starch content of both the test cultivars. Combined sulphate and $2 \mu \mathrm{M}$ selenate had a negligible promotive effect on roots and inhibitory effect on shoots of cv. satabdi whereas in cv. khitish, the starch content were overall inhibited slightly with respect to water control. Subsequent addition of $10 \mu \mathrm{M}, 20 \mu \mathrm{M}$ and $50 \mu \mathrm{M}$ selenate sulphate solutions

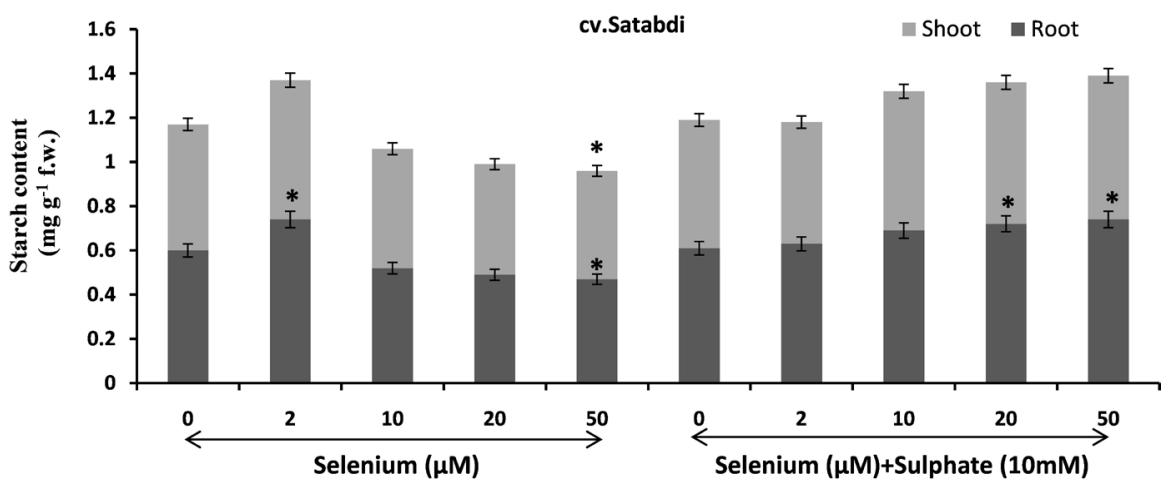

(a)

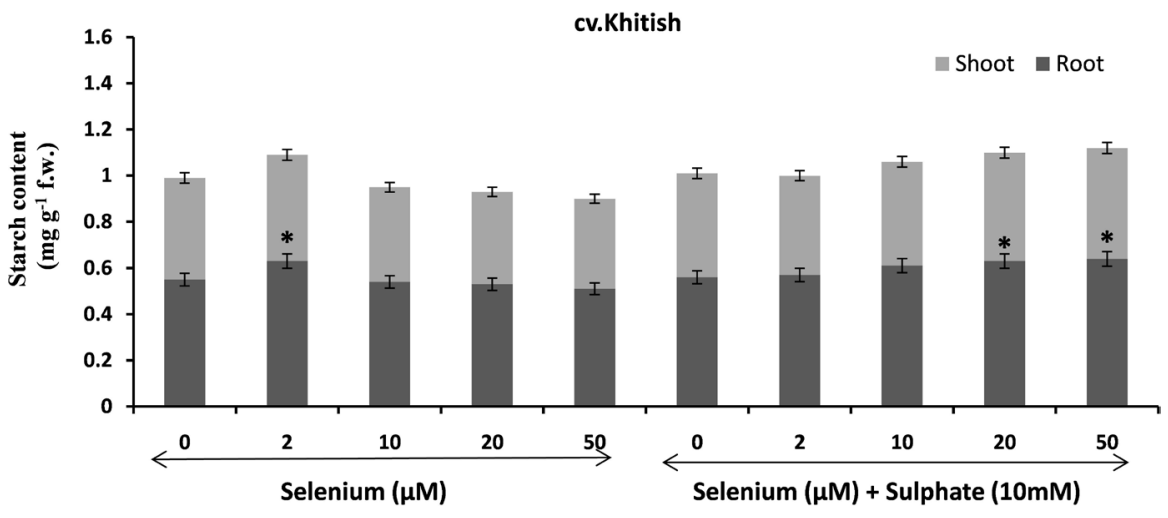

(b) 


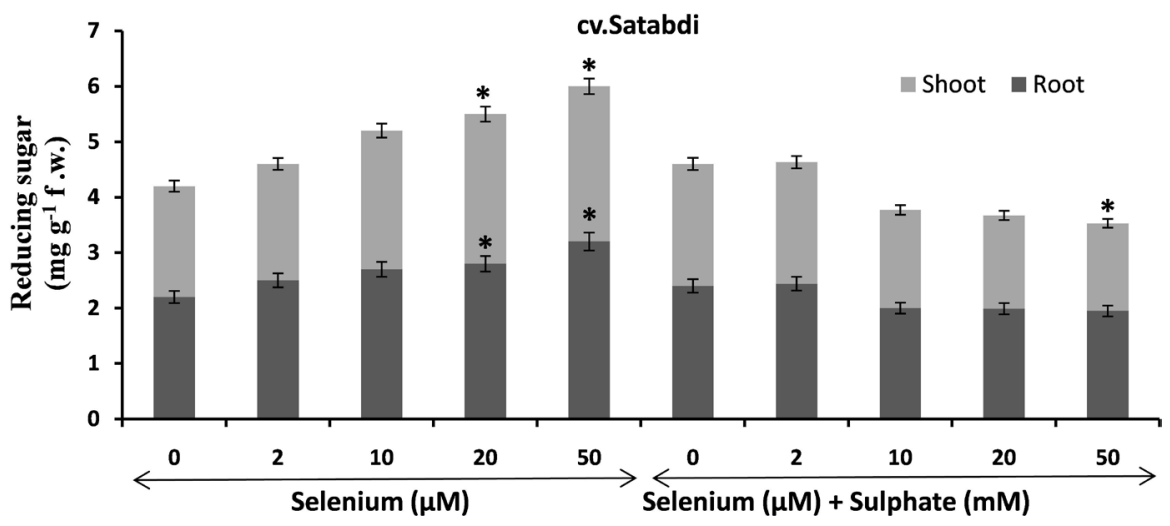

(c)

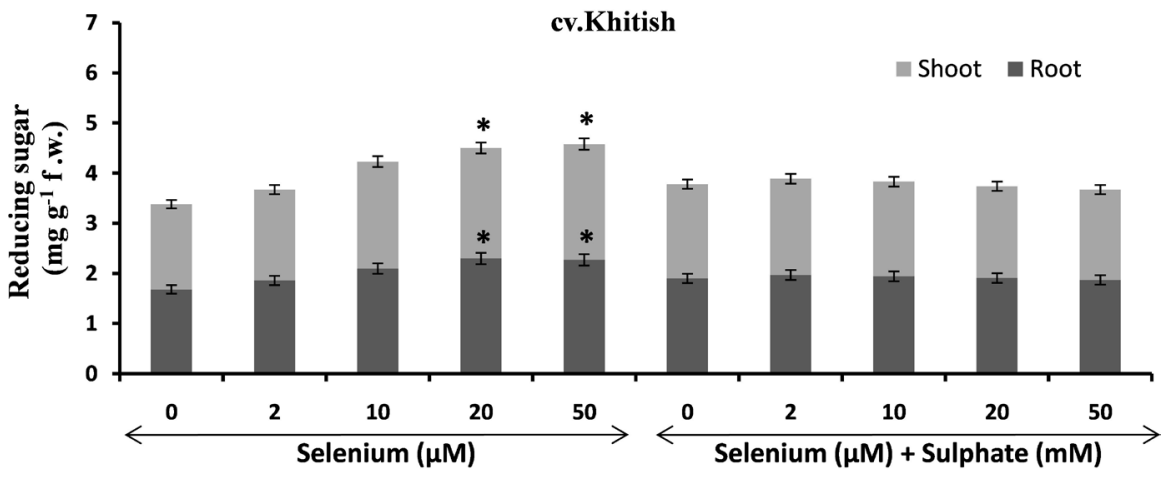

(d)

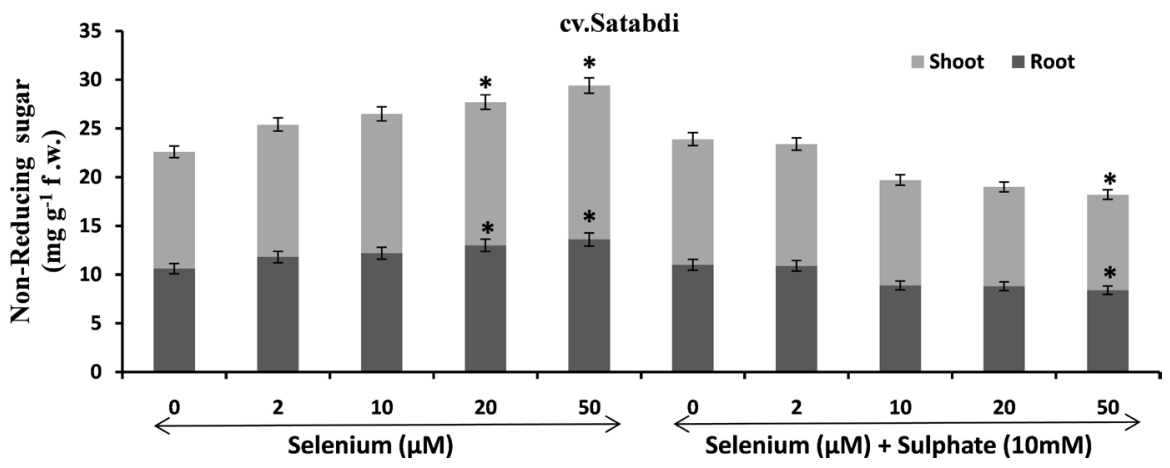

(e)

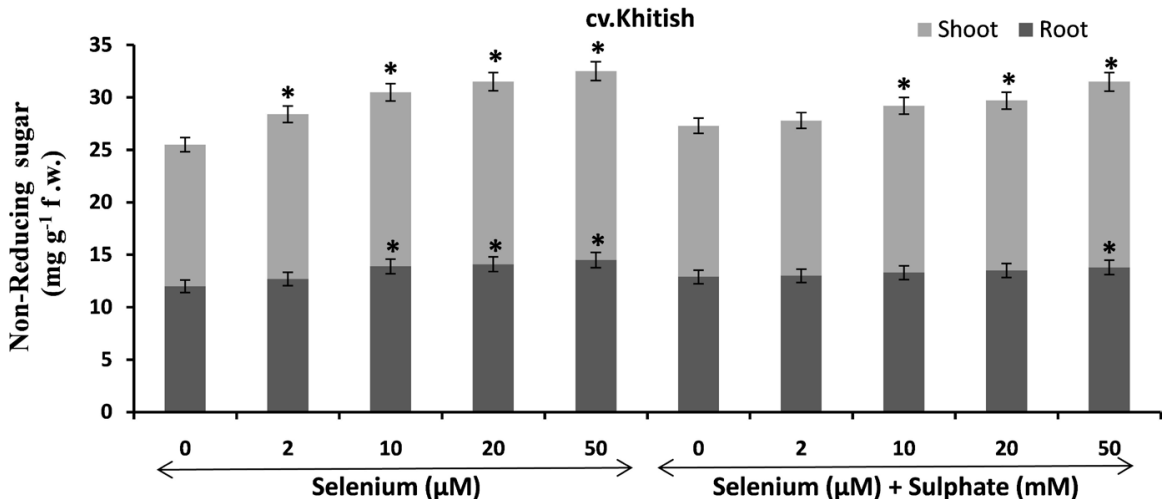

(f)

Figure 9. (a) Effect of various concentrations of selenate and/or sulphate (10 mM) applied either alone or in their combination on the starch content of rice (cv. satabdi) seed- 
lings. Values are the mean \pm SE of three repeats with two replicas in each treatment, *indicates statistically significant at $\mathrm{p} \leq 0.05$ respectively compared to control. (b) Effect of various concentrations of selenate and/or sulphate $(10 \mathrm{mM})$ applied either alone or in their combination on the starch content of rice (cv. khitish) seedlings. Values are the mean \pm SE of three repeats with two replicas in each treatment, ${ }^{*}$ indicates statistically significant at $\mathrm{p} \leq 0.05$ respectively compared to control. (c) Effect of various concentrations of selenate and/or sulphate $(10 \mathrm{mM})$ applied either alone or in their combination on the reducing sugar content of rice (cv. satabdi) seedlings. Values are the mean \pm SE of three repeats with two replicas in each treatment, ${ }^{*}$ indicates statistically significant at $\mathrm{p} \leq$ 0.05 respectively compared to control. (d) Effect of various concentrations of selenate and/or sulphate $(10 \mathrm{mM})$ applied either alone or in their combination on the reducing sugar content of rice (cv. khitish) seedlings. Values are the mean \pm SE of three repeats with two replicas in each treatment, ${ }^{*}$ indicates statistically significant at $\mathrm{p} \leq 0.05$ respectively compared to control. (e) Effect of various concentrations of selenate and/or sulphate $(10 \mathrm{mM})$ applied either alone or in their combination on the non reducing sugar content of rice (cv. satabdi) seedlings. Values are the mean \pm SE of three repeats with two replicas in each treatment, ${ }^{*}$ indicates statistically significant at $\mathrm{p} \leq 0.05$ respectively compared to control. (f) Effect of various concentrations of selenate and/or sulphate (10 mM) applied either alone or in their combination on the non reducing sugar content of rice (cv. khitish) seedlings. Values are the mean \pm SE of three repeats with two replicas in each treatment, ${ }^{*}$ indicates statistically significant at $\mathrm{p} \leq 0.05$ respectively compared to control.

promoted starch content on an average by about $15 \%, 20 \%$ and $23 \%$ in roots and by about $11 \%, 12 \%$ and $14 \%$ in shoots of $\mathrm{cv}$. satabdi. In cv. khitish co-application of $10 \mu \mathrm{M}, 20 \mu \mathrm{M}$ and $50 \mu \mathrm{M}$ selenate sulphate solutions increased starch content by about $2 \%, 5 \%$ and $7 \%$ in roots and by about $2 \%, 7 \%$ and $9 \%$ in shoots respectively over water control.

\subsubsection{Reducing Sugar}

A stimulatory effect on the reducing sugar content was observed in both roots and shoots of the test cultivars with increase in selenate concentrations. The reducing sugar content increased by about $14 \%$ and $9 \%$ in roots and shoots of $\mathrm{cv}$. satabdi and by about $11 \%$ and $7 \%$ in roots and shoots of $2 \mu \mathrm{M}$ treated seedlings of cv. khitish respectively. Addition of $10 \mu \mathrm{M}, 20 \mu \mathrm{M}$ and $50 \mu \mathrm{M}$ selenate to test solutions further increased the reducing sugar contents significantly in cv. satabdi by about $23 \%, 27 \%$ and $46 \%$ in roots and by about $25 \% 35 \%$ and $40 \%$ in shoots over control. Similarly it increased considerably by about $25 \%, 36 \%$ and $35 \%$ in roots and by about $25 \%, 29 \%$ and $36 \%$ in shoots of $\mathrm{cv}$. khitish rice seedlings under $10 \mu \mathrm{M}, 20 \mu \mathrm{M}$ and $50 \mu \mathrm{M}$ selenate treatment respectively over water control.

Simultaneous treatment with sulphate and selenate showed an ameliorative effect on the seedlings of test cultivars. At $2 \mu \mathrm{M}$ selenate and sulphate, the reducing sugar increased very little in seedlings of cv. satabdi whereas in cv. khitish it increased by about $17 \%$ in root and by about $13 \%$ in shoots over water control.Joint application of $10 \mu \mathrm{M}, 20 \mu \mathrm{M}$ and $50 \mu \mathrm{M}$ selenate along with sulphate decreased the reducing sugar level by about $9 \%, 10 \%$ and $11 \%$ in roots and by about $12 \%, 16 \%$ and $21 \%$ in shoots of cv. satabdi respectively. However, the reducing sugar content increased in cv. khitish under similar selenate 
sulphate treatment by about $16 \%, 14 \%$ and $11 \%$ in roots and $11 \%, 8 \%$ and $6 \%$ in shoots respectively over control but the increment were less compared to treatment with said concentrations of selenate only (Figure $9(c)$ and Figure $9(d)$ ).

\subsubsection{Non-Reducing Sugar}

The non reducing sugar content was enhanced in seedlings of both cultivars with increase in selenate concentrations. The non reducing sugar content were increased by about $12 \%$ and $13 \%$ in roots and shoots of $\mathrm{cv}$. satabdi as against $6 \%$ in roots and $16 \%$ in shoots of $2 \mu \mathrm{M}$ treated seedlings of cv.khitish respectively. Further in cv.satabdi, the non reducing sugar level increased by about 15\%, 23\% and $28 \%$ in roots and by about $19 \%, 23 \%$ and $32 \%$ in shoots under $10 \mu \mathrm{M}, 20$ $\mu \mathrm{M}$ and $50 \mu \mathrm{M}$ selenate treatment respectively over control. On a similar note the non reducing sugar level also increased in cv.khitish by about $16 \%, 18 \%$ and $21 \%$ in roots and by about $23 \%, 29 \%$ and $33 \%$ in shoots treated with $10 \mu \mathrm{M}, 20$ $\mu \mathrm{M}$ and $50 \mu \mathrm{M}$ selenate respectively over water control (Figure 9 (e) and Figure 9(f)).

The influence of selenate applied singly on the test seedlings were reversed by combined treatment with sulphate and said concentrations of selenate in both cultivars. At $2 \mu \mathrm{M}$ selenate and sulphate, the non reducing sugar increased on an average by about $12 \%$ in the test seedlings of $\mathrm{cv}$. satabdi whereas in $\mathrm{cv}$. khitish it increased by about $8 \%$ in root and about $3 \%$ in shoots over water control. Joint application of $10 \mu \mathrm{M}, 20 \mu \mathrm{M}$ and $50 \mu \mathrm{M}$ selenate individually along with sulphate decreased the non reducing sugar content by about $16 \%, 17 \%$ and $21 \%$ in roots and by about $10 \% 15 \%$ and $18 \%$ in shoots of $\mathrm{cv}$. satabdi respectively. However, in cv. khitish, the non reducing sugar contents increased by about $11 \%, 13 \%$ and $15 \%$ in roots and by about $18 \%, 20 \%$ and $31 \%$ in shoots under above mentioned selenate sulphate doses but the increment were less compared to seedlings treated with selenate alone with respect to water control.

\subsection{Effect on Mineral Nutrients}

\subsubsection{Selenium}

Compared to the control seedlings, accumulation of Se considerably increased in roots of test seedlings under $2 \mu \mathrm{M}$ selenate treatment which were about 4.3 $\mathrm{mg} \cdot \mathrm{Kg}^{-1} \mathrm{D}$.W.in $\mathrm{cv}$. satabdi and $2.7 \mathrm{mg} \cdot \mathrm{Kg}^{-1} \mathrm{D}$.W.in $\mathrm{cv}$. khitish. On the contrary, in shoots, similar treatment reduced the uptake of selenate by approximately half in both test cultivars with respect to control. Thereafter, a dose dependent steep incline in selenium level were observed in the rice seedlings treated with higher selenate concentrations. In both cv. satabdi and cv. khitish, the selenium concentration in roots increased 1000 fold in $2 \mu \mathrm{M}$ and $10 \mu \mathrm{M}$ treated seedlings followed by double that amount in $20 \mu \mathrm{M}$ and considerably more in $50 \mu \mathrm{M}$ treated test seedlings over control. Similar trend were observed in shoots where the selenium level significantly increased with increase in selenate concentration. In shoots, the selenium content linearly increased under $2 \mu \mathrm{M}, 10 \mu \mathrm{M}$ and $20 \mu \mathrm{M}$ selenate treatments by about $3 \mathrm{mg} \cdot \mathrm{Kg}^{-1} \mathrm{D}$.W., $15 \mathrm{mg} \cdot \mathrm{Kg}^{-1} \mathrm{D}$.W. and $23 \mathrm{mg} \cdot \mathrm{Kg}^{-1}$ 
D.W. respectively in cv. satabdi and by about $2 \mathrm{mg} \cdot \mathrm{Kg}^{-1} \mathrm{D} . \mathrm{W} ., 14 \mathrm{mg} \cdot \mathrm{Kg}^{-1} \mathrm{D}$.W. and $21 \mathrm{mg} \cdot \mathrm{Kg}^{-1} \mathrm{D} . \mathrm{W}$. respectively in cv. khitish. Maximum Se accumulation in shoots occurred in $50 \mu \mathrm{M}$ selenate treated rice seedlings which were about 31 $\mathrm{mg} \cdot \mathrm{Kg}^{-1} \mathrm{D}$.W. in cv. satabdi and about $33 \mathrm{mg} \cdot \mathrm{Kg}^{-1} \mathrm{D} . \mathrm{W}$. in $\mathrm{cv}$. khitish (Figure $10(\mathrm{a})$ and Figure 10(b)).

However, presence of sulphur in the medium seems to inhibit Se uptake in test seedlings of both cultivars. Co-application of selenium with sulphate reduced the accumulation of Se in roots of both cultivars with respect to water control. The Se level narrowed down in roots of rice seedlings jointly treated with $2 \mu \mathrm{M}, 10 \mu \mathrm{M}, 20 \mu \mathrm{M}, 50 \mu \mathrm{M}$ selenate and sulphate in contrast to selenium applied singly by about $6 \mathrm{mg} \cdot \mathrm{Kg}^{-1}$ D.W., $20 \mathrm{mg} \cdot \mathrm{Kg}^{-1}$ D.W., $45 \mathrm{mg} \cdot \mathrm{Kg}^{-1} \mathrm{D}$.W. and $46 \mathrm{mg} \cdot \mathrm{Kg}^{-1}$ D.W. respectively in $\mathrm{cv}$. satabdi and by about $4 \mathrm{mg} \cdot \mathrm{Kg}^{-1} \mathrm{D}$.W., 20 $\mathrm{mg} \cdot \mathrm{Kg}^{-1}$ D.W., $40 \mathrm{mg} \cdot \mathrm{Kg}^{-1}$ D.W and $118 \mathrm{mg} \cdot \mathrm{Kg}^{-1}$ D.W. respectively in $\mathrm{cv}$. khitish. However, in shoots, the Se content initially increased under $2 \mu \mathrm{M}$ selenate and sulphate treatment with respect to its single application followed by a steady decline in its level under combined $10 \mu \mathrm{M}, 20 \mu \mathrm{M}$ and $50 \mu \mathrm{M}$ selenate and sulphate treatment in both cv. satabdi and cv. khitish.

\subsubsection{Sodium}

The Na content was associated with a marked increase in its level in roots and shoots of both cultivars treated with selenate. The $\mathrm{Na}$ content significantly increased by about $60 \%$ in roots and by about $115 \%$ in shoots of $\mathrm{cv}$. satabdi under $2 \mu \mathrm{M}$ selenate treatment. Similar effect was observed in $2 \mu \mathrm{M}$ selenate treated rice seedlings of $\mathrm{cv}$. khitish where the $\mathrm{Na}$ level increased by about $51 \%$ in roots and $92 \%$ in shoots with respect to water control. A significant rise in $\mathrm{Na}$ content by about $60 \%, 61 \%$ and $63 \%$ in roots and by about $120 \%, 127 \%$ and $142 \%$ in shoots of $\mathrm{cv}$. satabdi were observed under the influence of 10 $\mu \mathrm{M}, 20 \mu \mathrm{M}$ and $50 \mu \mathrm{M}$ selenate treatment respectively. Similar promotive effect were observed in cv. khitish where the $\mathrm{Na}$ content increased by about $57 \%, 66 \%$ and $76 \%$ in roots and by about $95 \%, 108 \%$ and $104 \%$ in shoots over water control.

Combined application of selenate and sulphate exhibited stimulatory effect on $\mathrm{Na}$ accumulation in the tissues of both test cultivars but at a lesser degree than observed in test seedlings treated with selenate alone. The Na contents increased by about $55 \%$ and $77 \%$ in roots and shoots respectively of $\mathrm{cv}$. satabdi under $2 \mu \mathrm{M}$ selenate and sulphate treatment. However, in cv. khitish, the level of $\mathrm{Na}$ ions initially decreased in roots by about $11 \%$ but registered a sharp increase by about $73 \%$ in shoots of $2 \mu \mathrm{M}$ selenate and sulphate treated rice seedlings. A linear increment in $\mathrm{Na}$ content by about $70 \%, 78 \%$ and $79 \%$ in roots and about $81 \%$, $87 \%$, and $90 \%$ in shoots of $\mathrm{cv}$. satabdi were observed when treated with $10 \mu \mathrm{M}$, $20 \mu \mathrm{M}$ and $50 \mu \mathrm{M}$ selenate and sulphate respectively over control. In cv. khitish, the $\mathrm{Na}$ content also increased by about $23 \%, 34 \%$ and $43 \%$ in roots and by about $89 \%, 103 \%$, and $96 \%$ in shoots of test seedlings under similar treatment with respect to control (Figure 10(c) and Figure 10(d)). 


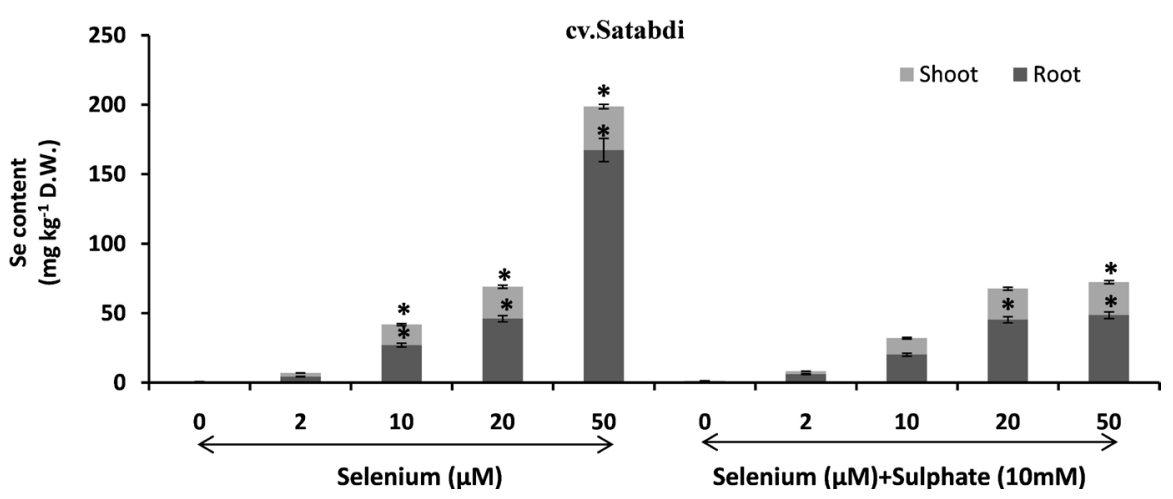

(a)

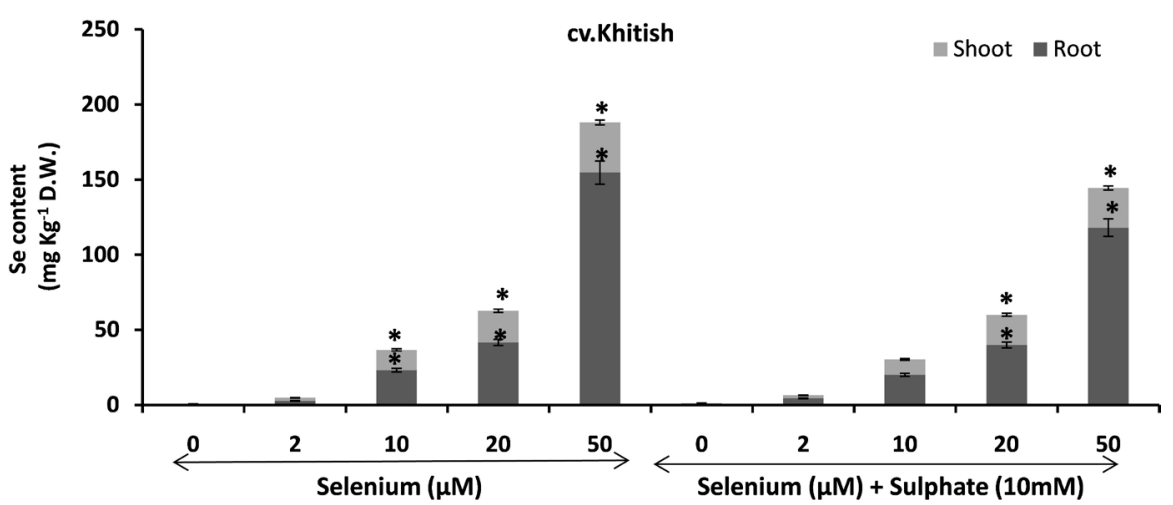

(b)

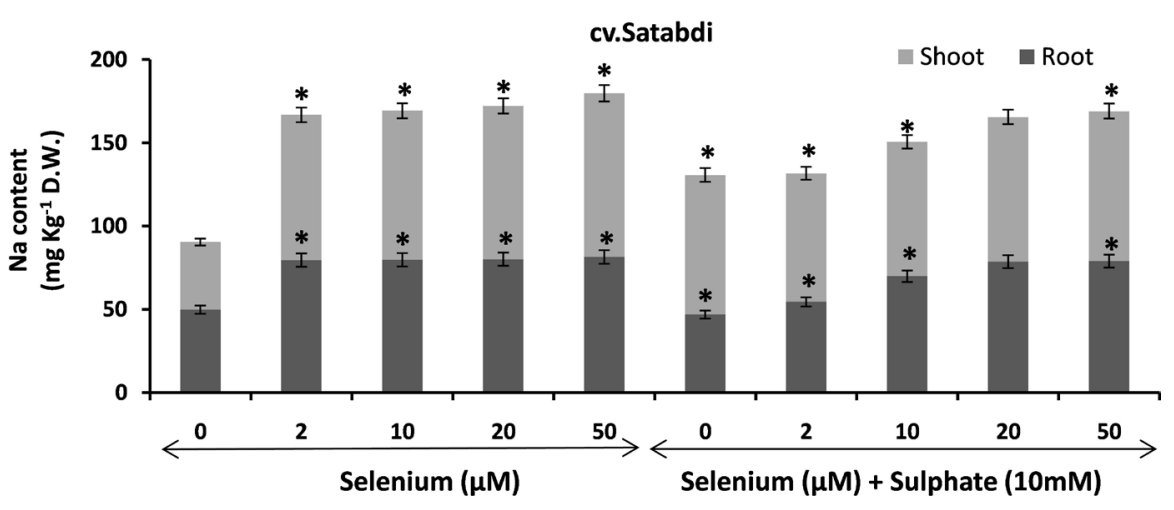

(c)

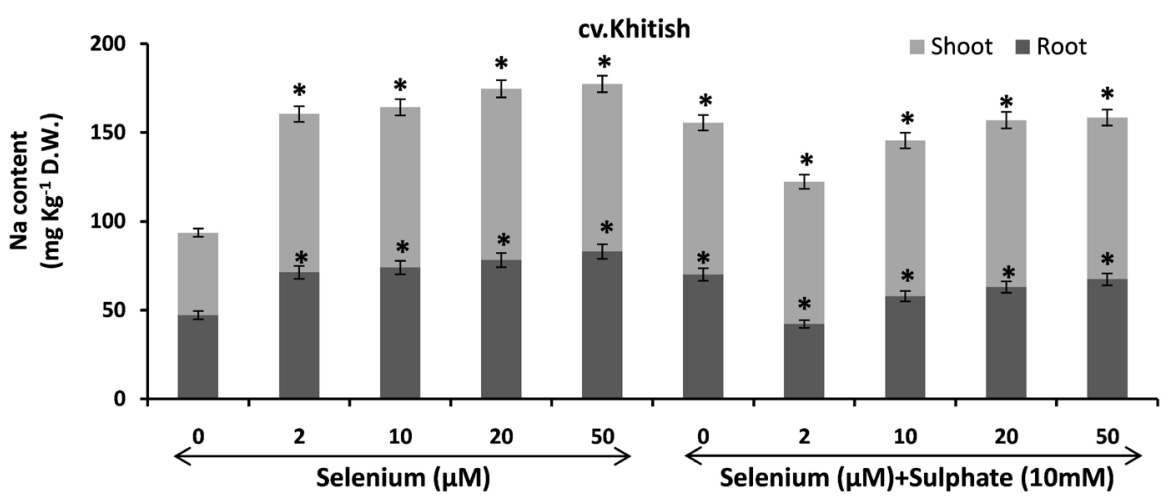

(d) 


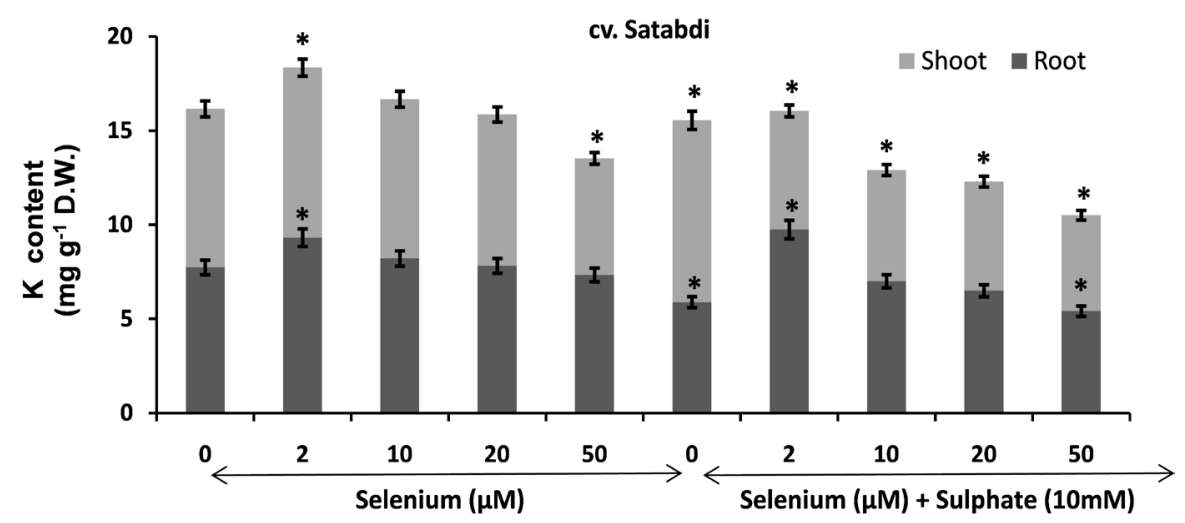

(e)

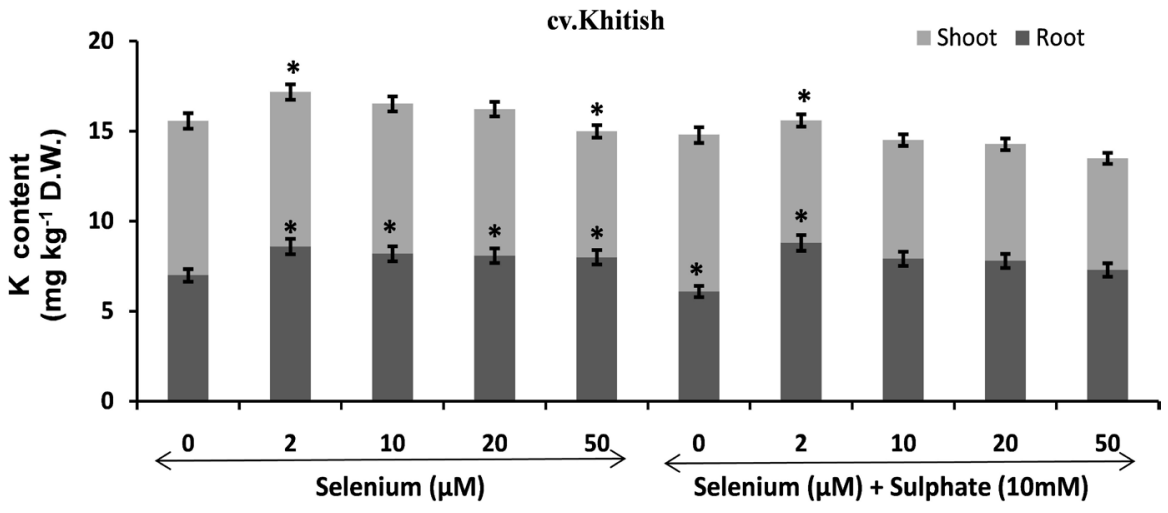

(f)

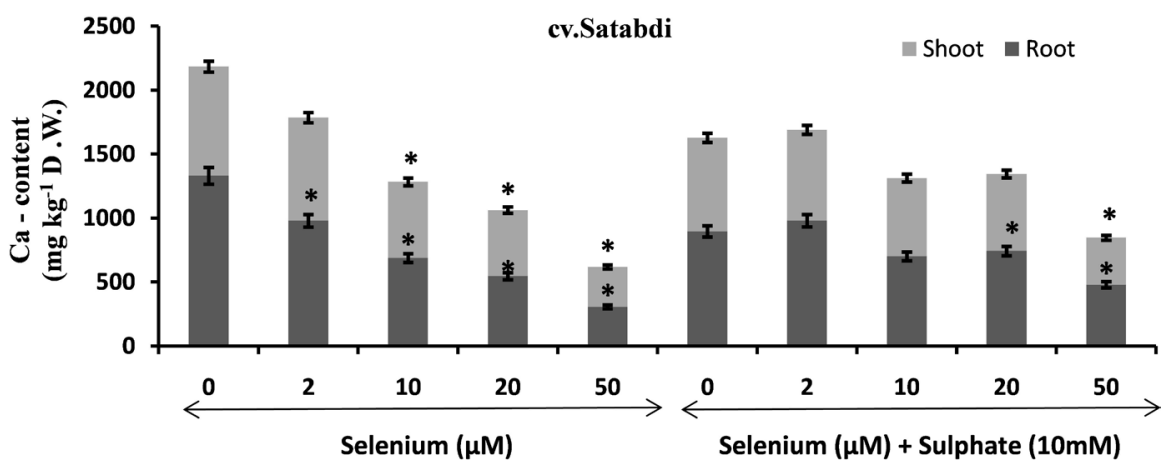

(g)

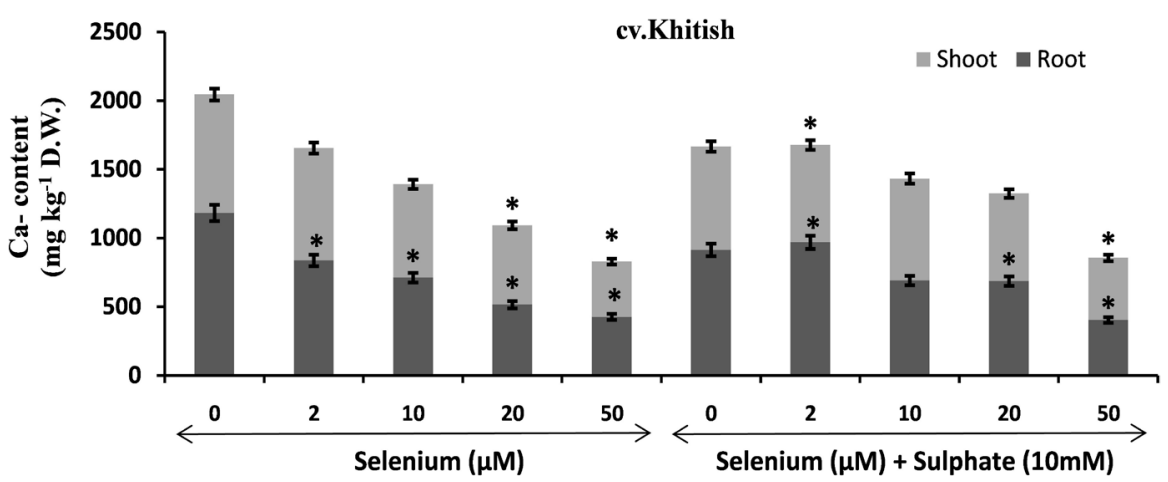

(h) 


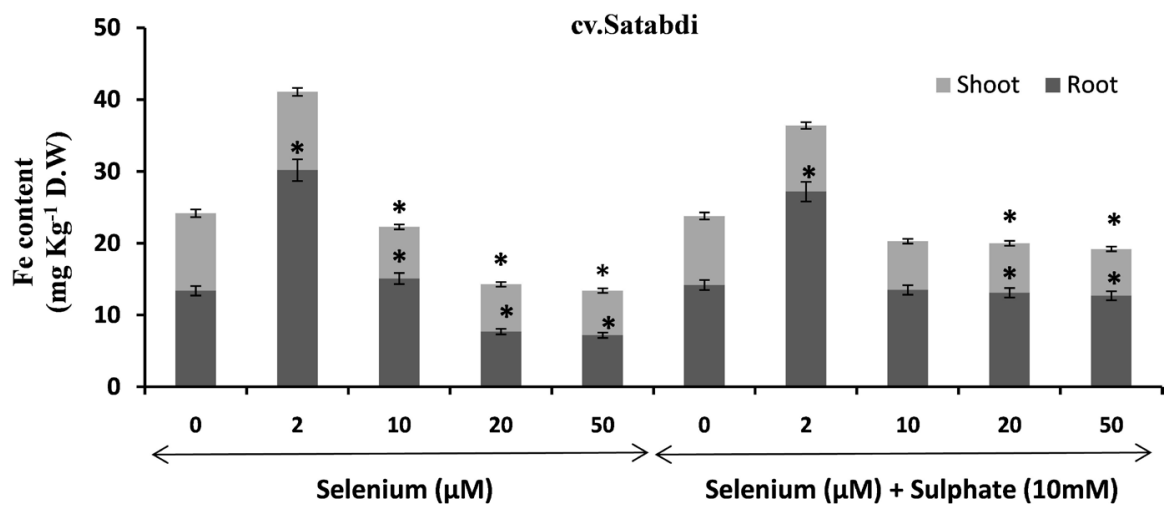

(i)

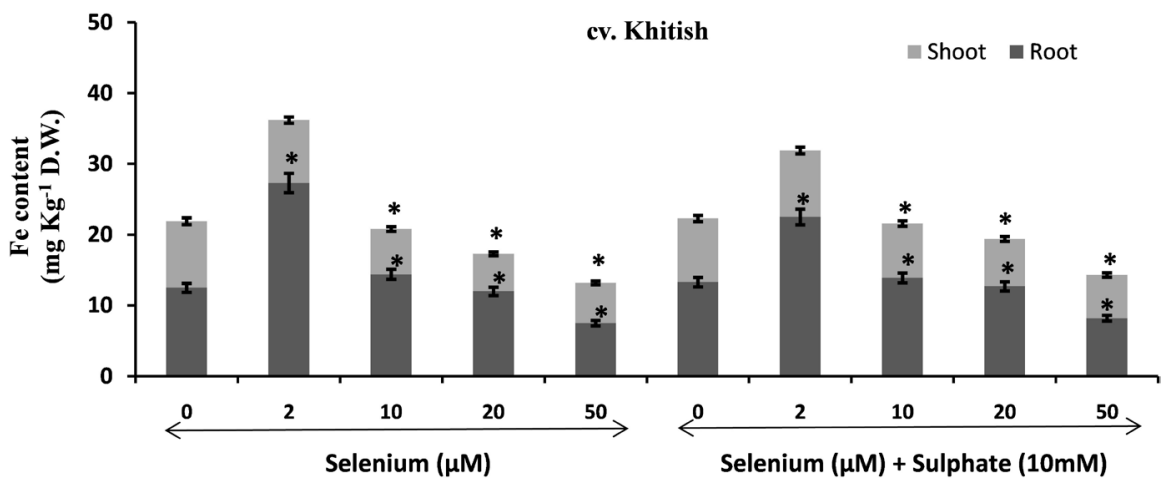

(j)

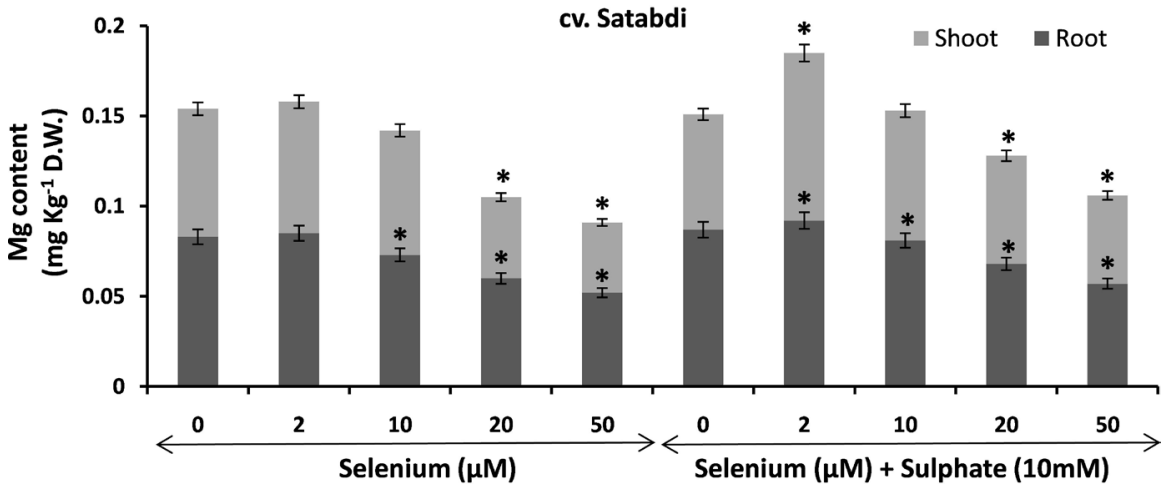

(k)

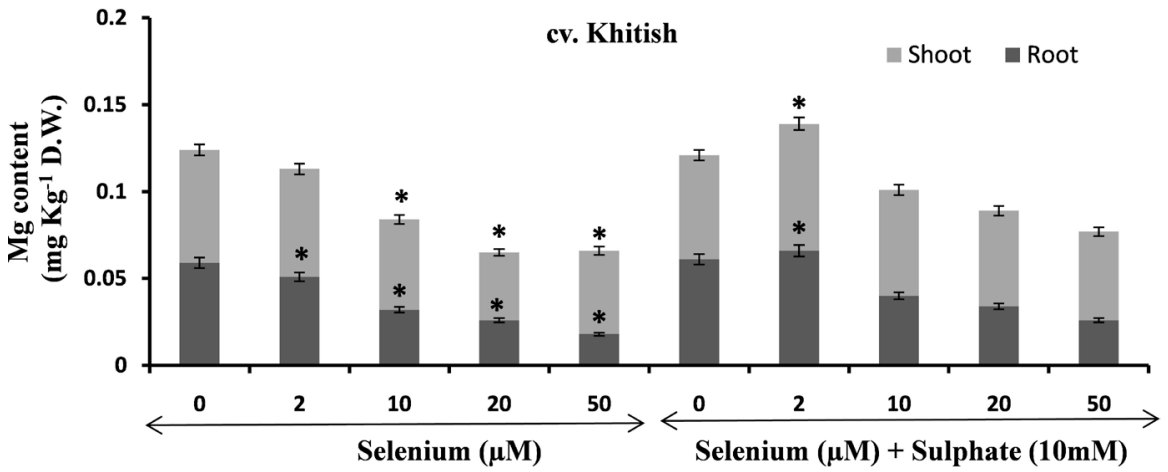

(l)

Figure 10. (a) Effect of selenate and sulphate applied singly or in combination on selenium content of twenty-one days old rice (cv. satabdi) seedlings. Values are the mean 
\pm SE of three repeats with two replicas in each treatment, ${ }^{*}$ indicates statistically significant at $\mathrm{p} \leq 0.05$ respectively compared to control. (b) Effect of selenate and sulphate applied singly or in combination on selenium content of twenty-one days old rice (cv. khitish) seedlings. Values are the mean \pm SE of three repeats with two replicas in each treatment, ${ }^{*}$ indicates statistically significant at $\mathrm{p} \leq 0.05$ respectively compared to control. (c) Effect of selenate and sulphate applied singly or in combination on sodium content of twenty-one days old rice (cv. satabdi) seedlings. Values are the mean \pm SE of three repeats with two replicas in each treatment, ${ }^{*}$ indicates statistically significant at $\mathrm{p} \leq 0.05$ respectively compared to control. (d) Effect of selenate and sulphate applied singly or in combination on sodium content of twenty-one days old rice (cv. khitish) seedlings. Values are the mean \pm SE of three repeats with two replicas in each treatment, ${ }^{*}$ indicates statistically significant at $\mathrm{p} \leq 0.05$ respectively compared to control. (e) Effect of selenate and sulphate applied singly or in combination on potassium content of twenty-one days old rice (cv. satabdi) seedlings. Values are the mean \pm SE of three repeats with two replicas in each treatment, ${ }^{*}$ indicates statistically significant at $\mathrm{p} \leq 0.05$ respectively compared to control. (f) Effect of selenate and sulphate applied singly or in combination on potassium content of twenty-one days old rice (cv. khitish) seedlings. Values are the mean \pm SE of three repeats with two replicas in each treatment, ${ }^{*}$ indicates statistically significant at $\mathrm{p} \leq 0.05$ respectively compared to control. (g) Effect of selenate and sulphate applied singly or in combination on calcium content of twenty-one days old rice (cv. satabdi) seedlings. Values are the mean \pm SE of three repeats with two replicas in each treatment, ${ }^{*}$ indicates statistically significant at $\mathrm{p} \leq 0.05$ respectively compared to control. (h) Effect of selenate and sulphate applied singly or in combination on calcium content of twenty-one days old rice (cv. khitish) seedlings. Values are the mean \pm SE of three repeats with two replicas in each treatment, ${ }^{*}$ indicates statistically significant at $\mathrm{p} \leq 0.05$ respectively compared to control. (i) Effect of selenate and sulphate applied singly or in combination on iron content of twenty-one days old rice (cv. satabdi) seedlings. Values are the mean \pm SE of three repeats with two replicas in each treatment, ${ }^{*}$ indicates statistically significant at $p \leq 0.05$ respectively compared to control. (j) Effect of selenate and sulphate applied singly or in combination on iron content of twenty-one days old rice (cv. khitish) seedlings. Values are the mean \pm SE of three repeats with two replicas in each treatment, ${ }^{*}$ indicates statistically significant at $\mathrm{p} \leq 0.05$ respectively compared to control. (k) Effect of selenate and sulphate applied singly or in combination on magnesium content of twenty-one days old rice (cv. satabdi) seedlings. Values are the mean \pm SE of three repeats with two replicas in each treatment, ${ }^{*}$ indicates statistically significant at $\mathrm{p} \leq 0.05$ respectively compared to control. (l) Effect of selenate and sulphate applied singly or in combination on magnesium content of twenty-one days old rice (cv. khitish) seedlings. Values are the mean $\pm \mathrm{SE}$ of three repeats with two replicas in each treatment, ${ }^{*}$ indicates statistically significant at $\mathrm{p}$ $\leq 0.05$ respectively compared to control.

\subsubsection{Potassium}

Elevation in the level of $\mathrm{K}$ ions at low concentration followed by its loss at higher concentrations of selenate was observed in roots and shoots of both cultivars with respect to water control. The $\mathrm{K}$ ions increased by about $20 \%$ in roots and $7 \%$ in shoots of $\mathrm{cv}$. satabdi and by about $23 \%$ in roots and negligibly in roots of $\mathrm{cv}$. khitish under $2 \mu \mathrm{M}$ selenate treatment. Subsequently the K content increased in roots of cv. satabdi by about $6 \%$ and $1 \%$ in $10 \mu \mathrm{M}$ and $20 \mu \mathrm{M}$ selenate respectively till it was inhibited by about $5 \%$ under $50 \mu \mathrm{M}$ selenate treatment. Further the negligible decline of about $1 \%$ and $5 \%$ in $\mathrm{K}$ content in $10 \mu \mathrm{M}$ and $20 \mu \mathrm{M}$ treated shoots of $\mathrm{cv}$. satabdi respectively reached a maximum inhibition of $28 \%$ under $50 \mu \mathrm{M}$ selenate treatment. In $\mathrm{cv}$. khitish, the stimulatory effect on the $\mathrm{K}$ 
contents in roots narrowed down by about $17 \%, 16 \%$ and $14 \%$ whereas in shoots the $\mathrm{K}$ level decreased by about $2 \%, 3 \%$ and $16 \%$ in rice seedlings under $10 \mu \mathrm{M}$, $20 \mu \mathrm{M}$ and $50 \mu \mathrm{M}$ selenate treatment respectively over control.

Simultaneous administration of selenate and $10 \mathrm{mM}$ sulphate adversely affected the level of $\mathrm{K}$ ions in roots and shoots of both test cultivars. At $2 \mu \mathrm{M}$ selenate sulphate treatment the $\mathrm{K}$ contents increased by about $26 \%$ in roots and decreased by about $27 \%$ in shoots of cv.satabdi. Thereafter the $\mathrm{K}$ contents linearly decreased by about $9 \%, 16 \%$ and $30 \%$ in roots and by about $30 \%, 32 \%$ and $41 \%$ in shoots of $\mathrm{cv}$. satabdi treated with $10 \mu \mathrm{M}, 20 \mu \mathrm{M}$ and $50 \mu \mathrm{M}$ selenate along with $10 \mathrm{mM}$ sulphate respectively. Similarly, in cv. khitish the stimulatory effect on $\mathrm{K}$ ions in roots decreased by about $26 \%, 13 \%, 11 \%$ and $4 \%$ and in shoots by about $19 \%, 22 \%, 25 \%$ and $26 \%$ in seedlings treated with $2 \mu \mathrm{M} 10 \mu \mathrm{M}, 20 \mu \mathrm{M}$ and $50 \mu \mathrm{M}$ selenate and sulphate respectively over control (Figure 10(e) and Figure $10(\mathrm{f}))$.

\subsubsection{Calcium}

A strong inhibitory effect on Ca content were observed at higher selenate concentrations in both roots and shoots of the test cultivars. The Ca content decreased by about $26 \%$ and $29 \%$ in roots and by about $6 \%$ and $5 \%$ in shoots of 2 $\mu \mathrm{M}$ treated rice seedlings of $\mathrm{cv}$. satabdi and $\mathrm{cv}$. khitish respectively. Further a steep decline by about $48 \%, 59 \%$ and $77 \%$ in roots and by about $30 \%, 40 \%$ and $64 \%$ in shoots of $\mathrm{cv}$. satabdi test seedlings were observed when treated with 10 $\mu \mathrm{M}, 20 \mu \mathrm{M}$ and $50 \mu \mathrm{M}$ selenate solution over water control. Similarly in cv. khitish, the Ca content were inhibited by about $40 \%, 56 \%$ and $64 \%$ in roots and by about $14 \%, 33 \%$ and $53 \%$ in shoots of rice seedlings treated with $10 \mu \mathrm{M}, 20$ $\mu \mathrm{M}$ and $50 \mu \mathrm{M}$ selenate respectively (Figure $10(\mathrm{~g})$ and Figure 10(h)).

The effect caused by selenate applied singly were partially ameliorated in both roots and shoots of test cultivars by joint application of said concentrations of selenate and $10 \mathrm{mM}$ sulphate. The Ca content decreased by about $26 \%$ and $18 \%$ in roots and by about $17 \%$ and $18 \%$ in shoots of $\mathrm{cv}$. satabdi and cv. khitish treated with combined solution of sulphate and $2 \mu \mathrm{M}$ selenate respectively. Co-application of selenate $(10 \mu \mathrm{M}, 20 \mu \mathrm{M}$ and $50 \mu \mathrm{M})$ and sulphate also decreased the Ca content considerably by about $47 \%, 44 \%$ and $64 \%$ in roots and by about $28 \%, 29 \%$ and $57 \%$ in shoots of cv. satabdi respectively. Similar trend was reflected in cv. khitish where the Ca content decreased by about $42 \%, 42 \%$ and $66 \%$ in roots and about $21 \%, 26 \%$ and $48 \%$ in shoots respectively over control.

\subsubsection{Iron}

Selenate treatments decreased Fe content in both root as well as shoot of both the test cultivars. Under $2 \mu \mathrm{M}$ selenate, the Fe content increased on an average by about $63 \%$ in cv. satabdi compared to an increment of about $57 \%$ on an average in cv. khitish over control. The Fe content declined by about $1 \%, 42 \%$ and $46 \%$ in roots of $\mathrm{cv}$. satabdi under $10 \mu \mathrm{M}, 20 \mu \mathrm{M}$ and $50 \mu \mathrm{M}$ selenate treatments respectively over control. In cv. khitish, Fe content increased by about $11 \%$ un- 
der $10 \mu \mathrm{M}$ selenate treatment. However, under $20 \mu \mathrm{M}$ and $50 \mu \mathrm{M}$ selenate treatments the Fe content declined by about $4 \%$ and $40 \%$ respectively over control. Similarly in shoot, $\mathrm{Fe}$ content declined by about $37 \%, 36 \%$ and $40 \%$ in $\mathrm{cv}$. satabdi and by about 5\%, 32\% and $44 \%$ in cv. khitish respectively under said treatments over control.

The effect of selenate treatment was ameliorated to certain extent on application of said concentrations of selenate and sulphate jointly in the test cultivars. At $2 \mu \mathrm{M}$ selenate and sulphate treatment, Fe content in root increased by about $103 \%$ and $80 \%$ in cv. satabdi and cv. khitish respectively over control. Similar treatments in shoot revealed a decrease of about $15 \%$ in the said content in cv. satabdi while in cv. khitish the Fe content equalled the control. Application of sulphate combined with $10 \mu \mathrm{M}$ selenate in cv. satabdi enhanced Fe content in roots by about $13 \%$ but caused a decline of about $2 \%$ and $5 \%$ under 20 $\mu \mathrm{M} \mathrm{Se}+\mathrm{SO}_{4}$ and $50 \mu \mathrm{M} \mathrm{Se}+\mathrm{SO}_{4}$ doses. In shoots, however, Fe content declined by about $33 \%, 39 \%$ and $43 \%$ under identical treatments. In cv. khitish roots, joint treatment of sulphate with selenate enhanced Fe content under $10 \mu \mathrm{M} \mathrm{Se}+$ $\mathrm{SO}_{4}$ and $20 \mu \mathrm{M} \mathrm{Se}+\mathrm{SO}_{4}$ doses by about $8 \%$ on an average while under $50 \mu \mathrm{M} \mathrm{Se}$ $+\mathrm{SO}_{4}$, the Fe content declined by about $34 \%$ with respect to control seedlings. In shoots, the Fe content decreased by about 18\%, 29\% and 35\% under the stated doses over control (Figure 10(i) and Figure 10(j)).

\subsubsection{Magnesium}

The Magnesium content decreased with increase in selenate concentrations in both roots and shoots of $\mathrm{cv}$. satabdi and $\mathrm{cv}$. khitish. In $2 \mu \mathrm{M}$ selenate treated root of cv. satabdi, the $\mathrm{Mg}$ content declined by about $14 \%$ while it increased by about $2 \%$ in root of cv. khitish under similar treatment. Thereafter, in roots the $\mathrm{Mg}$ content declined significantly by about $46 \%, 56 \%$ and $70 \%$ in cv. satabdi and by about $12 \%, 28 \%$ and $37 \%$ in $\mathrm{cv}$. Khitish under $10 \mu \mathrm{M}, 20 \mu \mathrm{M}$ and $50 \mu \mathrm{M}$ selenate treatments with respect to control. Co-application of sulphate along with selenate enhanced $\mathrm{Mg}$ contents in both cultivars in comparison to seedlings treated with selenate only. In roots, the $\mathrm{Mg}$ contents declined by about $32 \%, 42 \%$ and $56 \%$ in cv. satabdi under $10 \mu \mathrm{M} \mathrm{Se}+\mathrm{SO}_{4}, 20 \mu \mathrm{M} \mathrm{Se}+\mathrm{SO}_{4}$ and $50 \mu \mathrm{M} \mathrm{Se}+\mathrm{SO}_{4}$ treatments over control while in cv. Khitish the contents declined by about $2 \%$, $18 \%$ and $31 \%$ under similar treatments. However, under $2 \mu \mathrm{M} \mathrm{Se}+\mathrm{SO}_{4}$ treatment, increments of about $3 \%$ and $11 \%$ were noted in cv. satabdi and cv. khitish roots respectively over control (Figure 10(k) and Figure 10(1)).

In cv. satabdi shoot, $\mathrm{Mg}$ content declined by about $3 \%, 37 \%$ and $45 \%$ under 10 $\mu \mathrm{M}, 20 \mu \mathrm{M}$ and $50 \mu \mathrm{M}$ selenate treatments respectively over control. However, in cv. khitish the said decline was by about $20 \%, 26 \%$ and $40 \%$ under similar treatments compared to control. Under $2 \mu \mathrm{M}$ selenate treatment in cv. satabdi, $\mathrm{Mg}$ content increased by about $3 \%$ in contrast to a decline of about $5 \%$ in cv. khitish over control. Co-application of sulphate along with selenate enhanced Mg contents when compared to the individually selenate treated seedlings in both the cultivars. The $\mathrm{Mg}$ contents enhanced by about $31 \%$ in cv. satabdi while in $\mathrm{cv}$. 
khitish an increment of about $12 \%$ was documented under $2 \mu \mathrm{M} \mathrm{Se}+\mathrm{SO}_{4}$ treatment. Under $10 \mu \mathrm{M} \mathrm{Se}+\mathrm{SO}_{4}$ treatment an increase in the said content by about $1 \%$ was noted in cv. satabdi while a decline of about $16 \%$ and $31 \%$ occurred under $20 \mu \mathrm{M} \mathrm{Se}+\mathrm{SO}_{4}$ and $50 \mu \mathrm{M} \mathrm{Se}+\mathrm{SO}_{4}$ treatments. In cv. khitish however, a decline by about $6 \%, 15 \%$ and $22 \%$ occurred under $10 \mu \mathrm{M} \mathrm{Se}+\mathrm{SO}_{4}, 20 \mu \mathrm{M} \mathrm{Se}+$ $\mathrm{SO}_{4}$ and $50 \mu \mathrm{M} \mathrm{Se}+\mathrm{SO}_{4}$ treatments over control.

\section{Discussion}

Stress in any form restrict development and may cause lethal changes in living organisms. Interaction with contaminants such as metalloids or heavy metals leads to accumulation of ROS or singlet oxygen species that influences the integrity of the cells. In order to counteract such damages, both animals and plants have developed an antioxidant system comprising of enzymatic viz., SOD, CPX, CAT and non enzymatic antioxidants. Bio fortification by enhancing essential nutrient elements in crop plants viz., rice, wheat and maize has been documented to prevent malnutrition, especially in children and also fortifies the plant cells from various stresses.

Sodium selenate $\left(\mathrm{Na}_{2} \mathrm{SeO}_{4}\right)$ used in the present study acts as antioxidant at low concentration $(\leq 10 \mu \mathrm{M}$ selenate) and prevents or eliminates build up of harmful ROS. However, at higher concentrations ( $\geq 10 \mu \mathrm{M}$ selenate) it behaves as a prooxidant and induces ROS formation leading to oxidative stress (7). Our study similarly revealed the nutritive role of selenate $(2 \mu \mathrm{M})$ in contrast to its higher concentrations $(\geq 10 \mu \mathrm{M})$ where symptoms of necrosis and reduction in growth were noticed in both the test cultivars with prominent effects in cv. satabdi in comparison to that of $\mathrm{cv}$. khitish. Such promotive influence of selenate at low concentration $(2 \mu \mathrm{M})$ compared to higher doses $(\geq 10 \mu \mathrm{M})$ was evident from the phenotypic variations in contrast to higher doses where growth was restricted. Decline in growth was accompanied by apical browning, necrosis and chlorosis along with a decline in water content in both the cultivars. Our results are in line with studies conducted by Simaei et al. and Hawrylak-Nowak in tomato and lettuce respectively [46] [47]. However, the degree of decline in growth was much more in cv. satabdi compared to that of cv. khitish.

Effects of selenate in the test cultivars could be modulated by the presence or absence of sulphate in the treatment solution. Uptake of selenium in the plant tissue is regulated by sulphate transporters since the chalcogens, selenium and sulphur compete for the same transport pathway for entry to the cells. Application of sulphate with selenate helped to overcome the detrimental effects of selenate alone on growth and water content of the tested cultivars probably due to the antagonistic effects of sulphate and selenate ions for entry into the plant tissue.

Accumulation of Se in the plant tissues of the test cultivars showed a directly proportional relationship with increase in Se concentrations. The results obtained in our study corroborates with those obtained in other agricultural crops such as in Triticum aestivum by Broadley et al. [48] and by Freeman et al. [49] in 
Stanleya pinnata. Further, the test seedlings treated with both selenate and sulphate showed less uptake leading to lower Se content over control which may be the result of competition for preferential entry between sulphate and selenate primarily through sulphate tranporters in plants [49].

Photosynthetic pigments like chlorophyll and carotenoids are adversely affected by high Se concentrations [47] [50] [51]. In the current study, the total chlorophyll contents including chlorophyll a and chlorophyll $b$ declined with increase in Se concentrations in the test seedlings. Such negative influence of Se on porphobilinogen synthesis was also observed in Sinapis alba L. by Fargasova et al. [52]. However, the assimilatory pigments like carotenoids showed a dose dependent effect on test seedlings and registered an increase with increase in concentrations of selenate. The increase in carotenoid contents may well act to protect the plant tissue from oxidative stress. Similar increase in carotenoid levels under high Se concentrations were obtained in rocket plants by Khattab [9]. Combined application of sulphate and selenate ameliorated the effect of selenate on the photosynthetic pigments to some degree and increased chlorophyll a and chlorophyll $b$ contents of rice seedlings of both test cultivars. This may be attributed to beneficial effect of low concentration of Se as well as its chalcogen nature with sulphate which might restrict entry of Se salt at higher concentrations thus protecting the chloroplast enzymes and increasing the biosynthesis of photosynthetic pigments. Previous studies have established that the intensity of fluorescence emission bands or band ratios is directly related to the development of plants under stress [53]. The fluctuations in chlorophyll contents due to stress is the result of changes occurring in the chlorophyll apparatus which in turn might alter the fluorescence emission and prevent from fully converting the harvested light energy to its chemical form [54]. A reduction of the pigment content in the case of increasing levels of heavy metals and metalloids was previously observed in Arabidopsis thaliana by Baek [55]. Study on stress induced in maize plant under the influence of Ni found that it not only disrupts the photosynthetic apparatus by destroying mesophyll tissue thereby decreasing the chlorophyll contents [56], it also severely affects the electron transport chain and its intermediates. Inhibitory effects of increasing Ni concentrations on Hill activity of spinach leaves were also studied by Boisvert et al. [57]. All these evidences support our findings in which Se also exerted a similar influence on the rate of Hill reaction in both the test cultivars.

Selenium exerted a dose dependent effect on the plant tissues of the test cultivars which in turn enhanced the activities of antioxidant enzyme like SOD but not CPX and CAT in the rice seedlings [58]. There were considerable increase in level of oxidative stress markers like Proline, $\mathrm{H}_{2} \mathrm{O}_{2}$ and MDA with increase in selenate concentrations in the test seedlings. Similar observations were recorded in different crop species where the level of antioxidants and oxidative stress markers increased in order to withstand ROS formation during salt stress [58] [59] [60] [61]. The results obtained in our study are further supported by recent 
evidences where exogenous supplementation of $\mathrm{Na}_{2} \mathrm{SeO}_{4}$ was found to uplift the activity of various antioxidant enzymes such as SOD, CPX and CAT thereby protecting the plants from oxidative stress [62] [63] [64] [65].Our observations are also in agreement with previous studies in salinity stressed seedlings of rapeseed and Anethum graveolens where supplementary selenium in test solutions led to considerable increase in activity of SOD, CPX and CAT [18] [66].

The level of non toxic, low molecular weight compatible solutes also increases due to salinity stress in plants. The accumulation of such solutes helps to protect the plants from cellular damage induced during salinity stress by preventing or alleviating ROS formation and maintaining membrane integrity of the cells [67]. Proline is a major compatible solute which counteract the harmful effects of ROS by acting as a molecular chaperone and binding with the metal ions [68]. Results obtained in our study corroborates with such views as the proline level increased substantially with increase in concentrations of applied selenate. Similar results were also shown to occur where exogenous application of selenate improved proline concentrations in canola [69] and cucumber seedlings [47] under various abiotic stresses [68].

Abiotic stresses leads to photo-oxidative reactions causing significant increase in level of superoxide radicals and $\mathrm{H}_{2} \mathrm{O}_{2}$ content in the cells. Such accumulation of superoxide radicals and $\mathrm{H}_{2} \mathrm{O}_{2}$ in turn degrades the membranes integrity of thylakoids and chloroplasts resulting in chlorophyll degradation [69]. Increase in $\mathrm{H}_{2} \mathrm{O}_{2}$ levels due to salinity stress promotes cell shrinkage, chromatin condensation, DNA fragmentation and apoptosis in cells [70]. In our study, there was significant elevation in $\mathrm{H}_{2} \mathrm{O}_{2}$ contents which coincides with the decrease in chlorophyll level in the test seedlings of both cultivars under the influence of higher selenate concentrations. The results also indicates that supplementing the test solutions with both sulphate and $\mathrm{Na}_{2} \mathrm{SeO}_{4}$ effectively reduced the damage caused by selenate alone by preventing the degradation of chloroplasts and increasing the chlorophyll contents in the test cultivars. Peroxidation of lipids measured by MDA levels in plant cells are strong indicators of oxidative stress [71]. In our study, the MDA levels in rice seedlings consistently increased when treated with higher concentrations of selenium compared to the control plants. The opposite effect were observed in test seedlings treated with both sulphate and selenate. This suggest that combined application of sulphate and selenate helped in reducing MDA level in treated seedlings by lowering lipid peroxidation thereby protecting the membranes by improving the activity of the antioxidant enzymes.

Accumulation of carbohydrate products occurs in plant tissues to combat various stress conditions [72]. Sucrose and starch are the end products of the photosynthetically fixed carbon in plant cells. Starch acts as a temporary storage form of fixed carbon in the chloroplast and is finally stored in the cereal grains [73]. Sucrose, after synthesis in cytosol is transported to different organs of the seedlings for various metabolic activities [74]. Studies made by Dubey [75] and Devi et al., [76] have shown that soluble sugar increases under salt and cadmium 
stress. According to Couee et al., 2006 [77] such increase in the level of soluble sugars acts as a counteractive way to maintain homeostasis within plant cells. These views are supported by results obtained in our study on the two cultivars of rice in which the total sugar content including reducing and non reducing sugars were increased with increase in Se concentrations. The present result also corroborates to the fact that starch level concomitantly decreased with rise in soluble sugar contents in both cultivars. Inhibitory effect on starch mobility may have caused the reduction in starch content. Our observations are supported by studies made by Rahoui et al, 2010 [78] in cadmium treated seedlings of Vicia faba.

Reportedly production of ROS induces depolarization in cell membrane resulting in modified translocation of ions such as efflux of chloride and potassium ions and influx of calcium ions. Studies have shown that under salinity stress, plant cells accumulate more $\mathrm{Na}$ ions leading to oxidative damages due to disturbances occurring in ionic balance and metabolic activities. The status of $\mathrm{K}$ ions also poses as a limiting factor during salinity stress [79]. Increase in $\mathrm{Na}$ ions lowers the relative water content (RWC) in salinity stressed plants as it causes sodicity restricting root growth which in turn reduces the water mobility, hydraulic conductivity and functionality of aquaporins, thus minimizing the transport of water to the aerial parts [80]. According to Fu et al. [81] differential expression of $\mathrm{Na}$ and $\mathrm{K}$ transporters is also responsible for the differences observed in $\mathrm{Na} / \mathrm{K}$ homeostasis and salt tolerance between cereals like barley and rice. Further research is required to completely understand and elucidate the mode of action of sodium selenate in this area. In the current study, rice seedlings treated with $\mathrm{Na}_{2} \mathrm{SeO}_{4}$ showed accumulation of $\mathrm{Na}$ ions and $\mathrm{K}$ ions with increase in selenate concentrations which was amended by co-application with sulphate thus exhibiting better development and growth in the test seedlings. Combined sulphate and selenate application may have reduced the sequestering of said cations and diminished their toxic effects on the rice seedlings compared to control (seedlings grown in solution without selenate or sulphate). Similar observations were made by Rios et al. [82] where Ca concentration in lettuce plants treated with selenium salt decreased but $\mathrm{K}$ concentration increased. Increase in $\mathrm{K}$ level was also observed in wheat plant treated with selenium salt [83]. In plants, $\mathrm{Ca}$ is involved in cell wall strengthening and cell division, and is the second messenger in osmoregulation [84]. Iron is considered to be essential in normal growth and development in plants. Iron is also an essential component and an important co factor for enzymes like superoxide dismutase, peroxidase and catalase and is invariably involved in chlorophyll biosynthesis and photosynthesis [85]. Study made by Feng and Wei [86] suggest that high concentrations of selenium induces maximum Fe absorption compared to lower Se concentrations which shows reduced absorption of Fe ions. Similar result has been observed in our experiments where the Fe contents decreased linearly with increase in concentrations of selenate which also correlates to degradation of 
chlorophyll synthesis observed as more etiolated aerial parts in rice seedlings treated with high selenate levels. The influence of Selenium in plants is conspicuous through modifications in the concentrations of certain ions as a result of possible alterations in their absorption or due to changes occurring in the permeability coefficient of cellular membranes [87]. Therefore, the variable changes in level of $\mathrm{Na}, \mathrm{K}, \mathrm{Ca}$ and $\mathrm{Fe}$ observed in our study could possibly be due to these ions being involved in the regulation of cell membrane potential in the rice seedlings of both cultivars treated with selenate.

\section{Conclusion}

Sodium selenate $\left(\mathrm{Na}_{2} \mathrm{SeO}_{4}\right)$ acts as both antioxidant and prooxidant depending on the concentrations applied. Lower concentration of selenate $(2 \mu \mathrm{M})$ had a promotive effect and increased the nutritional capacity in the test cultivars enhancing growth and metabolism specifically in cv. satabdi. However, higher concentrations of selenate $(\geq 10 \mu \mathrm{M})$ led to gradual reduction in growth along with decrease in pigment contents, fluorescence intensity and Hill activity in the test cultivars. The oxidative stress markers and antioxidative enzymes were concomitantly altered along with considerable changes in ion contents. Accumulation of sugars occurred in the test seedlings in response to the oxidative stress incurred due to selenate treatments. However, the response was differential in the two rice cultivars cv. satabdi and cv. khitish, changes being more pronounced in cv. satabdi. Khitish being a comparatively tolerant variety succumbed to less damage than cv. satabdi. Application of sulphate $(10 \mathrm{mM})$ along with different test concentrations of selenate partially or almost completely ameliorated the toxic effects caused by selenate alone in the test seedlings. Combined sulphate and selenate was effective in countering the oxidative stress generated in the test seedlings under the influence of high selenium concentrations leading to better growth and metabolic activities in the test cultivars cv. satabdi and cv. khitish. The ameliorative influence was more pronounced in the sensitive variety cv. satabdi than in cv. khitish.

\section{Acknowledgements}

The authors are grateful to Centre of Advanced Study, Department of Botany, University of Calcutta for providing infrastructure facilities and to University Grants Commission, New Delhi for financial assistance for completion of the work.

\section{Conflicts of Interest}

The authors declare no conflicts of interest regarding the publication of this paper.

\section{References}

[1] Navarro-Alarcon, M. and Cabrera-Vique, C. (2008) Selenium in Food and the Hu- 
man Body: A Review. Science of the Total Environment, 400, 115-141. https://doi.org/10.1016/j.scitotenv.2008.06.024

[2] Terry, N., Zayed, A.M., de Souza, M.P. and Tarun, A.S. (2000) Selenium in Higher Plants. Annual Review of Plant Physiology and Plant Molecular Biology, 51, 401-432. https://doi.org/10.1146/annurev.arplant.51.1.401

[3] Bodnar, M., Konieczka, P. and Namiesnik, J. (2012) The Properties, Functions, and Use of Selenium Compounds in Living Organisms. Journal of Environmental Science and Health Part C, 30, 225-252. https://doi.org/10.1080/10590501.2012.705164

[4] Turakainen, M. (2007) Selenium and Its Effects on Growth, Yield and Tuber Quality in Potato. PhD Dissertation, Department of Applied Biology, University of Helsinki, Helsinki.

[5] Gigolashvili, T. and Kopriva, S. (2014) Transporters in Plant Sulphur Metabolism. Frontiers in Plant Science, 5, 422. https://doi.org/10.3389/fpls.2014.00442

[6] Kápolna, E., Laursen, K.H., Husted, S. and Larsen, E.H. (2012) Bio-Fortification and Isotopic Labelling of Se Metabolites in Onions and Carrots Following Foliar Application of Se and ${ }^{77}$ Se. Food Chemistry, 133, 650-657.

https://doi.org/10.1016/j.foodchem.2012.01.043

[7] Hartikainen, H., Xue, T. and Piironen, V. (2000) Selenium as an Antioxidant and Prooxidant in Ryegrass. Plant and Soil, 225, 193-200.

https://doi.org/10.1023/A:1026512921026

[8] Sun, H.W., Ha, J., Liang, S.X. and Kang, W.J. (2010) Protective Role of Selenium on Garlic Growth under Cadmium Stress. Communications in Soil Science and Plant Analysis, 41, 1195-1204. https://doi.org/10.1080/00103621003721395

[9] Khattab, H. (2004) Metabolic and Oxidative Responses Associated with Exposure of Eruca sativa (Rocket) Plants to Different Levels of Selenium. International Journal of Agriculture Biology, 6, 1101-1106.

[10] Sors, T.G., Ellis, D.R. and Salt, D.E. (2005) Selenium Uptake, Translocation, Assimilation Metabolic Fate in Plants. Photosynthesis Research, 86, 373-389. https://doi.org/10.1007/s11120-005-5222-9

[11] El Kassis, E., Cathala, E., Rouached, H., Fourcroy, P., Berthomieu, P., Terry, N., et al. (2007) Characterization of a Selenate-Resistant Arabidopsis Mutant. Root Growth as a Potential Target for Selenate Toxicity. Plant Physiology, 143, 1231-1241. https://doi.org/10.1104/pp.106.091462

[12] Cappa, J.J., Cappa, P.J., El Mehdawi, A.F., McAleer, J.M., Simmons, M.P. and Pilon-Smits, E.A. (2014) Characterization of Selenium and Sulfur Accumulation across the Genus Stanleya (Brassicaceae): A Field Survey and Common-Garden Experiment. American Journal of Botany, 101, 830-839. https://doi.org/10.3732/ajb.1400041

[13] Schiavon, M., Pittarello, M., Pilon-Smits, E.A.H., Wirtz, M., Hell, R. and Malagoli, M. (2012) Selenate and Molybdate Alter Sulfate Transport and Assimilation in Brassica juncea L. Czern.: Implications for Phytoremediation. Environmental and Experimental Botany, 75, 41-51. https://doi.org/10.1016/j.envexpbot.2011.08.016

[14] Kuznetsov, V.V., Kholodova, V., Kuznetsov, V.V. and Yagodin, B. (2003) Selenium Regulates the Water Status of Plants Exposed to Drought. Doklady Biological Sciences, 390, 266-268. https://doi.org/10.1023/A:1024426104894

[15] Djanaguiraman, M., Prasad, P. and Seppanen, M. (2010) Selenium Protects Sorghum Leaves from Oxidative Damage under High Temperature Stress by Enhancing Antioxidant Defense System. Plant Physiology and Biochemistry, 48, 999-1007. https://doi.org/10.1016/j.plaphy.2010.09.009 
[16] Cao, M.J., Wang, Z., Wirtz, M., Hell, R., Oliver, D.J. and Xiang, C.B. (2013) SULTR3; Is a Chloroplast-Localized Sulphate Transporter in Arabidopsis thaliana. The Plant Journal, 73, 607-616. https://doi.org/10.1111/tpj.12059

[17] Wu, Y.Y., Lu, X.Y., Peng, Z.K. and Luo, Z.M. (2000) Effect of Se on Physiological and Biochemical Characters of Paddy Rice. Scientia Agricultura Sinica, 33, 100-103.

[18] Hasanuzzaman, M., Hossain, M.A. and Fujita, M. (2011) Selenium-Induced Up-Regulation of the Antioxidant Defense and Methylglyoxal Detoxification System Reduces Salinity-Induced Damage in Rapeseed Seedlings. Biological Trace Element Research, 143, 1704-1721. https://doi.org/10.1007/s12011-011-8958-4

[19] Hondal, R.J., Marino, S.M. and Gladyshev, V.N. (2012) Selenocysteine in Thiol/Disulfide-Like Exchange Reactions. Antioxidants \& Redox Signaling, 18, 1675-1689. https://doi.org/10.1089/ars.2012.5013

[20] Akbulut, M. and Cakır, S. (2010) The Effects of Se Phytotoxicity on the Antioxidant Systems of Leaf Tissues in Barley (Hordeum vulgare L.) Seedlings. Plant Physiology and Biochemistry, 48, 160-166. https://doi.org/10.1016/j.plaphy.2009.11.001

[21] Łabanowska, M., Filek, M., Koscielniak, J., Kurdziel, M., Kulis, E. and Hartikainen, H. (2012) The Effects of Short-Term Selenium Stress on Polish and Finnish Wheat Seedlings-EPR, Enzymatic and Fluorescence Studies. Journal of Plant Physiology, 169, 275-284. https://doi.org/10.1016/j.jplph.2011.10.012

[22] Balk, J. and Pilon, M. (2011) Ancient and Essential: The Assembly of Iron-Sulfur Clusters in Plants. Trends in Plant Science, 16, 18-26. https://doi.org/10.1016/j.tplants.2010.12.006

[23] Schiavon, M., Moro, I., Pilon-Smits, E.A., Matozzo, V., Malagoli, M. and Dalla Vecchia, F. (2012) Accumulation of Selenium in Ulva sp. and Effects on Morphology, Ultrastructure and Antioxidant Enzymes and Metabolites. Aquatic Toxicology, 122-123, 222-231. https://doi.org/10.1016/i.aquatox.2012.06.014

[24] Horsfall, M.J., Abia, A.A. and Spiff, A.I. (2003) Removal of $\mathrm{Cu}(\mathrm{II})$ and $\mathrm{Zn}(\mathrm{II})$ Ions from Waste Water by Cassava (Manihot esculenta Cranz) Waste Biomass. African Journal of Biotechnology, 2, 360-364. https://doi.org/10.5897/AJB2003.000-1074

[25] Arinola, O.G., Nwozo, S.O., Ajiboye, J.A. and Oniye, A.H. (2008) Evaluation of Trace Elements and Total Antioxidant Status in Nigerian Cassava Processors. Pakistan Journal of Nutrition, 7, 770-772. https://doi.org/10.3923/pin.2008.770.772

[26] Garousi, F., Kovacs, B., Andrasi, D. and Veres, S. (2016) Selenium Phytoaccumulation by Sunflower Plants under Hydroponic Conditions. Water Air and Soil Pollution, 227, 382. https://doi.org/10.1007/s11270-016-3087-5

[27] Soetan, K.O., Olaiya, C.O. and Oyewole, O.E. (2010) The Importance of Mineral Elements for Humans, Domestic Animals and Plants: A Review. African Journal of Food Science, 4, 200-222.

[28] Barberon, M., Berthomieu, P., Clairotte, M., Shibagaki, N., Davidian, J.C. and Gosti, F. (2008) Unequal Functional Redundancy between the Two Arabidopsis thaliana High-Affinity Sulphate Transporters SULTR1;1 and SULTR1;2. New Phytologist, 180, 608-619. https://doi.org/10.1111/j.1469-8137.2008.02604.x

[29] White, P.J. and Broadley, M.R. (2009) Biofortification of Crops with Seven Mineral Elements Often Lacking in Human Diets-Iron, Zinc, Copper, Calcium, Magnesium, Selenium and Iodine. New Phytologist, 182, 49-84. https://doi.org/10.1111/j.1469-8137.2008.02738.x

[30] Velu, G., Ortiz-Monasterio, I., Cakmak, I., Hao, Y. and Singh, R.P. (2013) Biofortification Strategies to Increase Grain Zinc and Iron Concentrations in Wheat. Journal of Cereal Science, 59, 365-372. https://doi.org/10.1016/j.jcs.2013.09.001 
[31] Barrs, H.D. and Weatherly, P.E. (1962) A Re-Examination of Relative Turgidity for Estimating Water Deficits in Leaves. Australian Journal of Biological Sciences, 15, 413-428. https://doi.org/10.1071/BI9620413

[32] Paech, K. and Tracey, M.V. (1956) Modern Methods of Plant Analysis. Springer-Verlag, Berlin, Vol. 4, 143-196.

[33] Arnon, D.I. (1949) Copper Enzyme in Isolated Chloroplast. Plant Physiology, 24, 1-15. https://doi.org/10.1104/pp.24.1.1

[34] Mukherji, S. and Biswas, A.K. (1979) Modulation of Chlorophyll, Carotene and Xanthophyll Formation by Penicillin, Benzyladenine and Embryonic Axis in Mung Bean (Phaseolus aureus L.) Cotyledons. Annals of Botany, 43, 225-229. https://doi.org/10.1093/oxfordjournals.aob.a085627

[35] Vishniac, W. (1957) Methods for the Study of Hill Reaction. In: Colowick, S.P. and Kaplan, N.O., Eds., Methods in Enzymology, Academic Press, New York, Vol. 4, 342-355. https://doi.org/10.1016/0076-6879(57)04063-X

[36] Giannopolitis, C.N. and Ries, S.K. (1977) Superoxide Dismutases I. Occurrence in Higher Plants. Plant Physiology, 59, 309-314. https://doi.org/10.1104/pp.59.2.309

[37] Gasper, T. and Laccoppe, J. (1968) The Effect of CCC and AMO-1618 on Growth, Catalase, Peroxidase, IAA Oxidase Activity of Young Barley Seedlings. Physiologia Plantarum, 21, 1104-1109. https://doi.org/10.1111/j.1399-3054.1968.tb07338.x

[38] Chance, B. and Maehly, A.C. (1955) Assay of Catalases and Peroxidases. Methods in Enzymology, 2, 764-817. https://doi.org/10.1016/S0076-6879(55)02300-8

[39] Bates, L.S., Waldren, R.P. and Treare, I.D. (1973) Rapid Estimation of Free Proline for Water Stress Determination. Plant and Soil, 39, 205-207.

https://doi.org/10.1007/BF00018060

[40] Vellikova, V., Yordanov, I. and Edreva, A. (2000) Oxidative Stress and Some Antioxidant Systems in Acid Rain-Treated Bean Plants. Plant Science, 151, 59-66. https://doi.org/10.1016/S0168-9452(99)00197-1

[41] Hodges, D.M., DeLong, J.M., Forney, C.F. and Prange, R.K. (1999) Improving the Thiobarbituric Acid-Reactive-Substances Assay as for Estimating Lipid Peroxidation in Plant Tissues Containing Anthocyanin and Other Interfering Compounds. Planta, 207, 604-611. https://doi.org/10.1007/s004250050524

[42] Dubois, M., Gilles, K.A., Hamilton, J.K., Rebers, P.A. and Smith, F. (1956) Colorimetric Method for Determination of Sugars and Related Substances. Analytical Chemistry, 28, 350-356. https://doi.org/10.1021/ac60111a017

[43] Miller, G.L. (1972) Use of Dinitrosalicylic Acid Reagent for Determination of Reducing Sugars. Analytical Chemistry, 31, 426-428.

https://doi.org/10.1021/ac60147a030

[44] McCready, R.M., Guggolz, J., Silviera, V. and Owens, H.S. (1950) Determination of Starch and Amylase in Vegetables. Analytical Chemistry, 22, 1156-1158. https://doi.org/10.1021/ac60045a016

[45] Lowry, O.H., Rosebrough, N.J., Farr, A.L. and Randall, R.J. (1951) Protein Measurement with the Folin Phenol Reagent. The Journal of Biological Chemistry, 193, 265-275.

[46] Simaei, M., Khavarinejad, R.A., Saadatmand, S., et al. (2011) Interactive Effects of Salicylic Acid and Nitric Oxide on Soybean Plants under $\mathrm{NaCl}$ Salinity. Russian Journal of Plant Physiology, 58, Article No. 783. https://doi.org/10.1134/S1021443711050220

[47] Hawrylak-Nowak, B. (2009) Beneficial Effects of Exogenous Selenium in Cucumber 
Seedlings Subjected to Salt Stress. Biological Trace Element Research, 132, 259-269. https://doi.org/10.1007/s12011-009-8402-1

[48] Broadley, M.R., Alcock, J., Alford, J., Cartwright, P., Foot, I., Fairweather-Tait, S.J., et al. (2010) Selenium Biofortification of High-Yielding Winter Wheat (Triticum aestivum L.) by Liquid or Granular Se Fertilisation. Plant Soil, 332, 5-18.

https://doi.org/10.1007/s11104-009-0234-4

[49] Freeman, J.L., Tamaoki, M., Stushnoff, C., Quinn, C.F., Cappa, J.J., Devonshire, J., Fakra, S.F., Marcus, M.A., McGrath, S.P., Van Hoewyk, D., et al. (2010) Molecular Mechanisms of Selenium Tolerance and Hyperaccumulation in Stanleya pinnata. Plant Physiology, 153, 1630-1652. https://doi.org/10.1104/pp.110.156570

[50] Valkama, E., Kivimäenpää, M., Hartikainen, H. and Wulff, A. (2003) The Combined Effects of Enhanced UV-B Radiation and Selenium on Growth, Chlorophyll Fluorescence and Ultrastructure in Strawberry (Fragaria $\times$ ananassa) and Barley (Hordeum vulgare) Treated in the Field. Agricultural and Forest Meteorology, 120, 267-278. https://doi.org/10.1016/j.agrformet.2003.08.021

[51] Xue, T., Hartikainen, H. and Piironen, V. (2001) Antioxidative and Growth Promoting Effect of Selenium in Senescing Lettuce. Plant Soil, 237, 55-61. https://doi.org/10.1023/A:1013369804867

[52] Fargašová, A., Pastierová, J. and Svetková, K. (2006) Effect of Se-Metal Pair Combinations $(\mathrm{Cd}, \mathrm{Zn}, \mathrm{Cu}, \mathrm{Pb})$ on Photosynthetic Pigments Production and Metal Accumulation in Synapis alba L. Seedlings. Plant, Soil and Environment, 52, 8-15. https://doi.org/10.17221/3340-PSE

[53] Lichtenthaler, H.K. and Miehé, J.A. (1997) Fluorescence Imaging as a Diagnostic Tool for Plant Stress. Trends in Plant Science, 2, 316-320. https://doi.org/10.1016/S1360-1385(97)89954-2

[54] Huseynova, I.M. (2012) Photosynthetic Characteristics and Enzymatic Antioxidant Capacity of Leaves from Wheat Cultivars Exposed to Drought. Biochimica et Biophysica Acta, 1817, 1516-1523. https://doi.org/10.1016/j.bbabio.2012.02.037

[55] Baek, S., Han, T., Ahn, S., et al. (2012) Effects of Heavy Metals on Plant Growths and Pigment Contents in Arabidopsis thaliana. The Plant Pathology Journal, 28, 446-452. https://doi.org/10.5423/PPJ.NT.01.2012.0006

[56] Ghasemi, F., Heidari, R., Jameii, R. and Purakbar, L. (2012) Effects of $\mathrm{Ni}^{2+}$ Toxicity on Hill Reaction and Membrane Functionality in Maize. Journal of Stress Physiology \& Biochemistry, 8, 55-61.

[57] Boisvert, S., Joly, D., Leclerc, S., Govindachary, S., Harnois, J. and Carpentier, R. (2007) Inhibition of the Oxygen-Evolving Complex of Photo-System II and Depletion of Extrinsic Polypeptides by Nickel. Biometals, 20, 879-889.

https://doi.org/10.1007/s10534-007-9081-Z

[58] Józwiak, W. and Politycka, B. (2019) Effect of Selenium on Alleviating Oxidative Stress Caused by a Water Deficit in Cucumber Roots. Plants (Basel, Switzerland), 8, 217. https://doi.org/10.3390/plants8070217

[59] Kubala, S., Garnczarska, M., Wojtyla, L., Clippe, A., Kosmala, A. and Zmienko, A. (2015a) Deciphering Priming-Induced Improvement of Rapeseed (Brassica napus L.) Germination through an Integrated Transcriptomic and Proteomic Approach. Plant Science, 231, 94-113. https://doi.org/10.1016/j.plantsci.2014.11.008

[60] Kubala, S., Wojtyla, L., Quinet, M., Lechowska, K., Lutts, S. and Garnczarska, M. (2015b) Enhanced Expression of the Proline Synthesis Gene P5CSA in Relation to Seed Osmo Priming Improvement of Brassica napus Germination under Salinity Stress. Plant Science, 183, 1-12. https://doi.org/10.1016/j.jplph.2015.04.009 
[61] Shalaby, T., Bayoumi, Y., Alshaal, T., Elhawat, N., Sztrik, A. and El-Ramady, H. (2017) Selenium Fortification Induces Growth, Antioxidant Activity, Yield and Nutritional Quality of Lettuce in Salt-Affected Soil Using Foliar and Soil Applications. Plant Soil, 421, 245-258. https://doi.org/10.1007/s11104-017-3458-8

[62] Wang, C.Q. (2011) Water-Stress Mitigation by Selenium in Trifolium repens L. Journal of Plant Nutrition and Soil Science, 174, 276-282. https://doi.org/10.1002/jpln.200900011

[63] Malik, J.A., Goel, S., Kaur, N., Sharma, S., Singh, I. and Nayyar, H. (2012) Selenium Antagonises the Toxic Effects of Arsenic on Mungbean (Phaseolus aureus Roxb.) Plants by Restricting Its Uptake and Enhancing the Antioxidative and Detoxification Mechanisms. Environmental and Experimental Botany, 77, 242-248. https://doi.org/10.1016/j.envexpbot.2011.12.001

[64] Proietti, P., Luigi, N., Buono, D.D., D’Amato, R., Tedeschini, E., Daniele, D.B., et al. (2013) Selenium Protects Olive (Olea europaea L.) from Drought Stress. Scientia Horticulturae, 164, 165-171. https://doi.org/10.1016/j.scienta.2013.09.034

[65] Iqbal, M., Hussain, I., Liaqat, H., Ashraf, M.A., Rasheed, R. and Rehman, A.U. (2015) Exogenously Applied Selenium Reduces Oxidative Stress and Induces Heat Tolerance in Spring Wheat. Plant Physiology and Biochemistry, 94, 95-103. https://doi.org/10.1016/j.plaphy.2015.05.012

[66] Shekari, F., Abbasi, A. and Mustafavi, S.H. (2017) Effect of Silicon and Selenium on Enzymatic Changes and Productivity of Dill in Saline Condition. Journal of the Saudi Society of Agricultural Sciences, 16, 367-374. https://doi.org/10.1016/j.jssas.2015.11.006

[67] Subramanyam, K., Arun, M., Mariashibu, T.S., Theboral, J., Rajesh, M., Singh, N.K., et al. (2012) Overexpression of Tobacco Osmotin (Tbosm) in Soybean Conferred Resistance to Salinity Stress and Fungal Infections. Planta, 236, 1909-1925. https://doi.org/10.1007/s00425-012-1733-8

[68] Nawaz, F., Ashraf, M.Y., Ahmad, R., Waraich, E.A., Shabbir, R.N. and Bukhari, M.A. (2015) Supplemental Selenium Improves Wheat Grain Yield and Quality through Alterations in Biochemical Processes under Normal and Water Deficit Conditions. Food Chemistry, 175, 350-357. https://doi.org/10.1016/j.foodchem.2014.11.147

[69] Hashem, H.A., Hassanein, R.A., Bekheta, M.A. and El-Kady, F.A. (2013) Protective Role of Selenium in Canola (Brassica napus L.) Plant Subjected to Salt Stress. The Egyptian Journal of Experimental Biology, 9, 199-211.

[70] Houot, V., Etienne, P., Petitot, A.S., Barbier, S., Blein, J.P. and Suty, L. (2001) Hydrogen Peroxide Induces Programmed Cell Death Features in Cultured Tobacco BY-2 Cells, in a Dose-Dependent Manner. Journal of Experimental Botany, 52, 1721-1730. https://doi.org/10.1093/jxb/52.361.1721

[71] Farmer, E.E. and Mueller, M.J. (2013) ROS-Mediated Lipid Peroxidation and RES-Activated Signaling. Annual Review of Plant Biology, 64, 429-450. https://doi.org/10.1146/annurev-arplant-050312-120132

[72] Rosa, M., Prado, C., Podazza, G., Interdonato, R., González, J.A., Hilal, M. and Prado, F.E. (2009) Soluble Sugars-Metabolism, Sensing and Abiotic Stress: A Complex Network in the Life of Plants. Plant Signaling Behaviour, 4, 388-393. https://doi.org/10.4161/psb.4.5.8294

[73] Zeeman, S.C., Smith, S.M. and Smith, A.M. (2004) The Breakdown of Starch in Leaves. New Phytologist, 163, 247-261. https://doi.org/10.1111/j.1469-8137.2004.01101.x 
[74] Zhou, R., Silcher, R.C. and Quebedeau, B. (2002) Apple Leaf Sucrose Phosphatesynthase Is Inhibited by Sorbitol-6-Phosphate. Functional Plant Biology, 29, 569-574. https://doi.org/10.1071/PP01123

[75] Dubey, R.S. and Singh, A.K. (1999) Salinity Induces Accumulation of Soluble Sugars and Alter the Activity of Sugar Metabolizing Enzymes in Rice Plants. Biologia Plantarum, 42, 233-239. https://doi.org/10.1023/A:1002160618700

[76] Devi, R., Munjral, N., Gupta, A.K. and Kaur, N. (2007) Cadmium Induced Changes in Carbohydrate Status and Enzymes of Carbohydrate Metabolism, Glycolysis and Pentose Phosphate Pathway in Pea. Environmental and Experimental Botany, 61, 167-174. https://doi.org/10.1016/j.envexpbot.2007.05.006

[77] Couée, I., Sulmon, C., Gouesbet, G. and El Amrani, A. (2006) Involvement of Soluble Sugars in Reactive Oxygen Species Balance and Responses to Oxidative Stress in Plants. Journal of Experimental Botany, 57, 449-459. https://doi.org/10.1093/jxb/erj027

[78] Rahoui, S., Chaoui, A. and El Ferjani, E. (2010) Reserve Mobilization Disorder in Germinating Seeds of Vicia faba L. Exposed to Cadmium. Journal of Plant Nutrition, 33, 809-817. https://doi.org/10.1080/01904161003654055

[79] Hasegawa, P.M., Bressan, R.A., Zhu, J.K. and Bohnert, H.J. (2000) Plant Cellular and Molecular Responses to High Salinity. Annual Review of Plant Physiology and Plant Molecular Biology, 51, 463-499. https://doi.org/10.1146/annurev.arplant.51.1.463

[80] López-Berenguer, C., García-Viguera, C. and Carvajal, M. (2006) Are Root Hydraulic Conductivity Responses to Salinity Controlled by Aquaporins in Broccoli Plants? Plant Soil, 279, 13-23. https://doi.org/10.1007/s11104-005-7010-x

[81] Fu, L., Shen, Q., Kuang, L., Yu, J., Wu, D. and Zhang, G. (2018) Metabolite Profiling and Gene Expression of $\mathrm{Na} / \mathrm{K}$ Transporter Analyses Reveal Mechanisms of the Difference in Salt Tolerance between Barley and Rice. Plant Physiology and Biochemistry, 130, 248-257. https://doi.org/10.1016/j.plaphy.2018.07.013

[82] Ríos, J.J., Rosales, M.A., Blasco, B., Cervilha, L., Romero, L. and Ruiz, J.M. (2008) Biofortification of Se and Induction of the Antioxidant Capacity in Lettuce Plants. Scientia Horticulturae, 116, 248-255. https://doi.org/10.1016/j.scienta.2008.01.008

[83] Yao, X.Q., Chu, J.Z., He, X.L., Liu, B.B., Li, J.M., et al. (2013) Effects of Selenium on Agronomical Characters of Winter Wheat Exposed to Enhanced Ultra-Violet-B. Ecotoxicology and Environmental Safety, 92, 320-326. https://doi.org/10.1016/j.ecoenv.2013.03.024

[84] Filek, M., Keskinen, R., Hartikainen, H., Szarejko, I., Janiak, A., Miszalski, Z., et al. (2008) The Protective Role of Selenium in Rape Seedlings Subjected to Cadmium Stress. Journal of Plant Physiology, 165, 833-844. https://doi.org/10.1016/j.jplph.2007.06.006

[85] Nouet, C.C., Motte, P. and Hanikenne, M. (2011) Chloroplastic and Mitochondrial Metal Homeostasis. Trends in Plant Science, 16, 395-404.

https://doi.org/10.1016/j.tplants.2011.03.005

[86] Feng, R., Wei, C. and Tu, S. (2013) The Roles of Selenium in Protecting Plants against Abiotic Stresses. Environmental and Experimental Botany, 87, 58-68. https://doi.org/10.1016/j.envexpbot.2012.09.002

[87] Pazurkiewicz-Kocot, K., Galas, W. and Kita, A. (2003) The Effect of Selenium on the Accumulation of Some Metals in Zea mays L. Plants Treated with Indole-3-Acetic Acid. Cellular \& Molecular Biology Letters, 8, 97-103. 